"This is the peer reviewed version of the following article: Perks G, Maruyama S, (2017) The 'Flock' Phenomenon of the Sydney Lockout Laws: Dual Effects on Rental Prices, Economic Record,

93(303):517-533, which has been published in final form at https://doi.org/10.1111/1475-4932.12358.

This article may be used for non-commercial purposes in accordance with Wiley Terms and Conditions for Self-Archiving." 


\title{
The "Flock" Phenomenon of the Sydney Lockout Laws: Dual Effects on Rental Prices
}

\author{
Georgia Perks \\ Shiko Maruyama * \\ University of Technology Sydney \\ University of Technology Sydney \\ PO Box 123, Broadway, NSW 2007 \\ Australia \\ PO Box 123, Broadway, NSW 2007 \\ Australia
}

Email: Georgia.R.Perks@ @student.uts.edu.au

Email: shiko.maruyama@uts.edu.au

*Corresponding author

THIS VERSION: June 18, 2017 


\title{
The "Flock" Phenomenon of the Sydney Lockout Laws: Dual Effects on Rental Prices
}

\begin{abstract}
Geographically targeted crime control is a controversial attempt to alleviate crime, which risks the displacement of crime into neighbouring areas. The 2014 Sydney lockout laws have decreased the nightlife economy and violence in the entertainment districts having displaced them into neighbouring areas. We investigate the effect of the Sydney lockout laws on rental prices in the displacement areas, and find a relatively weak and short-lived negative effect on small dwellings and a persistent positive effect on large dwellings. Our results indicate the long-term positive effect of the lockout laws on the land value of surrounding areas despite reported crime displacement.
\end{abstract}

JEL Codes: K32; R2; R3

Keywords: Alcohol law; Geographically targeted crime control; Displacement; Housing markets; Difference-in-difference; Sydney 


\section{Introduction}

Geographically targeted crime control, which targets "hot spots" rather than the root cause of the crime phenomenon, is a controversial attempt to alleviate the incidence of criminal behaviour. Controversy exists over the concern that targeting the location of offences may lead to the displacement of crime into areas that are exempt from regulations, creating socio-spatial ghettos in bordering areas (Fischer et al., 2004; Bowers et al., 2011; Telep et al., 2014). The Sydney lockout laws, which were implemented in 2014 as part of the New South Wales Government's crackdown on drug and alcohol-fuelled violence, have restricted popular and iconic establishments in the once bustling Sydney Entertainment District (SED) (Spicer, 2015), and have diverted late night partygoers to alternative destinations that have bars, clubs, and other licensed venues (Ralston, 2015). There have been reports of increased violence and feelings of unsafety, including the death of a man in Waterloo as the result of a coward punch (Levy, 2015). A recent article by Donnelly et al. (2016) reports an increase in assaults at The Star casino, which is outside the SED, since the introduction of the lockout laws.

Evidence tends to show that the decrease in crime in targeted areas is much larger than the increase in crime in flock areas, implying the overall positive effect of geographically targeted policies (Guerette and Bowers, 2009; Bowers et al., 2011; Johnson et al., 2012; Telep et al., 2014). Donnelly et al. (2016) conclude that the increase in assaults at The Star Casino they find is much smaller than the decreases in assault in the SED areas after the lockout laws. Yet, the potentially negative impact on flock area communities inevitably leads to intense public debate. At the same time, the Sydney lockout laws have led to the displacement of nightlife entertainment as well (Spicer, 2015). The new function of flock areas as "trendy" entertainment hubs may be 
an attractive feature for certain individuals and may have contributed to local housing demand as a result of the proximity to nightlife or increased job opportunities. Because of these opposing effects of the laws on surrounding areas, the direction of the overall effect on the flock areas is theoretically indeterminate. The hasty passing of the lockout laws did not consider the possible unintended effect on surrounding areas, and despite a flood of media articles and concerns expressed by residents, there is little empirical evidence for the effect of the lockout laws on the displacement areas. Such evidence is critical in the cost-benefit consideration of geographically targeted crime control policies.

In this paper, we study the causal effect of the "flock" phenomenon of the Sydney lockout laws on rental prices in the local housing market. To separate the causal effect of the lockout laws from secular housing market trends, we rely on a quasiexperimental research design in which we apply a difference-in-difference (DID) approach to the postcode-level weekly rent data. Given our concern about potential heterogeneity in the causal effect, we also conduct sub-sample analysis to separately evaluate the causal effect by dwelling size.

A variety of methods are used in the literature to quantify the indirect and intangible cost of crime, such as hedonic regression (e.g. Tita, Petras, and Greenbaum, 2006) and the life satisfaction approach (e.g. Manning, Fleming, and Ambrey, 2015). In this paper, we follow the spirit of hedonic regression and assume that housing market prices provide sufficient statistics to measure the value of a local neighbourhood, because housing prices are determined by a market mechanism that reflects various short-term and long-term factors of the neighbourhood that buyers and sellers take into consideration. There are myriad studies on the negative effect of crime on local housing 
demand (Rizzo, 1979; Dubin and Goodman, 1982; Cullen and Levitt, 1999; Tita, Petras, and Greenbaum, 2006; Linden and Rockoff, 2008; Ihlanfeldt and Mayock, 2010; Klimova and Lee, 2014). Conversely, the Allen Consulting Group (2012) reports a positive relationship between the density of licensed premises and housing rental prices in New South Wales, which suggests that renters are attracted to areas with a high density of licensed premises. Bianchi (2015) also suggests that the culture of late-night drinking in entertainment venues may be a drawcard for young renters at the same time as causing increased security concerns for families. The standard hedonic approach may yield misleading estimates as a result of various confounding factors, but we employ a rigorous causal framework in a similar manner to other recent studies (Linden and Rockoff, 2008; Klimova and Lee, 2014). We study rental prices rather than housing prices, which is motivated by the following two facts: rental price data offer a substantially larger number of observations than housing price data, and rental prices react more quickly to exogenous changes than housing prices. The use of rental prices is therefore suitable for evaluating not only the long-term effect of the lockout laws but also the short-term effect.

Our results are summarised as follows. The overall-effect models show that the introduction of the lockout laws has had no statistically significant causal effect on median rental prices in displacement areas. However, sub-sample analysis reveals differential causal effects: a negative effect on one-bedroom dwellings and a positive effect on $3+$ bedroom dwellings. The former effect is relatively weak and short-lived, while the latter is persistent, indicating that the positive effect dominates in the long run. These opposite effects offset each other and consequently result in the insignificant estimate in the overall-effect models. We speculate that the differential effect arises 
because of spatial heterogeneity: smaller dwellings tend to be located closer to main bars and entertainment strips whereas larger dwellings tend to be in a quieter neighbourhood of the postcode. The dual effect of the lockout laws suggests that welldesigned geographically targeted alcohol control can be a cost-effective approach even when its effect on the displacement areas is taken into consideration.

\section{The Sydney Lockout Laws}

On 21 January 2014 the New South Wales State Government announced new restrictions on licensed premises to reduce alcohol-related violence. The legislation, which took effect on 24 February 2014, included a lockout of new patrons to hotels, registered clubs, nightclubs, and karaoke bars ${ }^{1}$ after 1:30 am in the Sydney Entertainment District (SED), which comprises the areas of Sydney Central Business District (CBD), Woolloomooloo, Potts Point, Kings Cross, and parts of Darlinghurst, including Oxford Street; cessation of alcohol service in these venues at 3:00 am; the banning of designated "troublemakers" from entering these venues; and a ban on takeaway alcohol sales after 10:00 pm across New South Wales (NSW Government, 2014; Donnelly et al., 2016). Given the prevalence of late-night drinking and predrinking culture in Australia (Miller et al., 2016), limiting late-night access to licensed venues has potential for significantly reducing alcohol-fuelled violence and crime.

Studies and reports offer clear evidence that the Sydney lockout laws have reduced the amount of alcohol related violence in the SED (Fulde et al., 2015; Menéndez et al., 2015; Ralston, 2015; Donnelly et al., 2016). Fulde et al. (2015) report a significant reduction in alcohol-related injuries and trauma presentations at a nearby

\footnotetext{
${ }^{1}$ Small bars (maximum 60 people), most restaurants, and tourism accommodation establishments are exempt. Venues currently licensed to stay open after 3:00 am can do so without alcohol service (NSW Government, 2014)
} 
hospital. Menéndez et al. (2015) also find that the Sydney lockout laws have reduced the incidence of assault in the Kings Cross and CBD entertainment precincts.

\section{Past Studies on the Effect of Nightlife Restriction Laws}

Violence in entertainment districts is a major problem across urban landscapes around the world, and geographically targeted crime control has been widely used (Braga et al., 2014). There is resounding evidence in both Australia and the world that government enforced restrictions on alcohol access reduce crime and violence. In Australia, lockout laws were implemented in the Newcastle CBD in March 2008, and Kypri et al. (2011) report a $37 \%$ decrease in assaults in the restricted area. Douglas (1998) studies the restriction of access to alcohol in the community of Halls Creek in Western Australia, and finds that a reduction in the trading hours of licenced premises is associated with a reduction in the consumption of alcohol, the incidence of crime, alcohol-related presentations at hospital, and the incidence of domestic violence. A significant reduction in the number of violent incidents due to lockout legislation is also reported for Queensland (Mazerolle et al., 2012). Internationally, Voas et al. (2002) report reduction in cross-border drinking as the result of the early closure of bars around the US-Mexico border. Mandatory early closure of bars and restaurants also reduced homicides, violence, and deaths by car accidents in the São Paolo Metropolitan Areas (Biderman et al., 2010). In Amsterdam, the reverse was shown to occur when extended opening hours correlated with a significant increase in alcohol-related injuries and violence (De Goeij et al., 2015). Permitting weekend alcohol sales also resulted in increase in crime in the US (Heaton, 2012) and Sweden (Grönqvist and Niknami, 2014). Most of the above studies employ a rigorous causal evaluation framework, and the 
literature has by now accumulated plenty of evidence for the general effectiveness of restrictions on alcohol access on crime prevention.

The evidence for the effect of lockout laws on displacement areas is mixed and relatively scarce. Although most studies are observational rather than based on a rigorous quasi-experimental design, a series of reviews have found that the displacement of crime, if any, is uncommon and small (Guerette and Bowers, 2009; Bowers et al., 2011; Johnson et al., 2012; Telep et al., 2014). In Australia, Kypri et al. (2011) report that there has been no overall geographic displacement of assault from the Newcastle CBD to a nearby area with a similar night-time economy. Mazerolle et al. (2011) also find no displacement of violence to surrounding areas following lockout legislation in Queensland. In the case of the Sydney lockout laws, however, the geographical displacement of violence and crime has been reported as discussed above (Levy, 2015; Donnelly et al. 2016), whereas Menéndez et al. (2015) do not find statistically significant changes in displacement areas.

\section{Data}

\subsection{Data Sources and Sample Selection}

The main dataset is drawn from the Rent and Sales Reports, a quarterly report of weekly rents in the greater metropolitan region of Sydney published by the NSW Government's Housing department. ${ }^{2}$ Using the supplementary table 'A1: Median Weekly Rents Greater Metropolitan Region by Postcodes - All Dwellings' (NSW Government: Family \& Community Services, 2015), we compile quarterly postcode-level panel data that provide the median weekly rental price by number of bedrooms $-1,2,3$, and $4+$

\footnotetext{
2 The data are publicly accessible from the 'Reports, Plans \& Paper' section at the website of Housing NSW, the NSW Government's housing department, www.housing.nsw.gov.au.
} 
bedrooms. In the report, the median rental price is left blank if less than ten active bonds are registered in the postcode, but missing values are rare due to our focus on inner-city areas, where a large number of rental properties are always on the market.

The main analysis relies on data from the June 2013, September 2013, December 2013, June 2014, September 2014, December 2014, March 2015, June 2015, September 2015, and December 2015 tables (NSW Government: Family \& Community Services, 2015, Issues 104, 105, 106, 108, 109, 110, 111, 112, 113, and 114, respectively). The March 2014 dataset is excluded from the analysis because it relates to the period between 1st January 2014 and 31st March 2014, in which the announcement and subsequent implementation of the lockout laws took place. The time frame of our analysis therefore utilises three quarterly periods before the announcement of the lockout laws (June 2013 - December 2013) and seven quarterly periods after the implementation of the laws (June 2014 - December 2015). Although data before June 2013 is available, we choose the 2013 June quarter as the starting point of our analysis because the data from March reports tend to be noisy due to a downturn in the Sydney real estate market during the Christmas and New Year period, which is followed by a revival in February (NSW Government: Fair Trading 2014). Utilising the data of seven periods after the implementation of the lockout laws benefits our statistical inference by providing a larger number of observations; however, including such a long period might attenuate the causal effect we hope to estimate, especially if the effect of the lockout laws exists only for a short term. To address this concern, we also conduct a robustness analysis that uses only three periods after the introduction of the lockout laws. 


\subsection{Flock and Control Groups}

Table 1 lists the postcode areas used in our analysis as the displacement or "flock" areas. Because there is no unique, objective way to classify areas into the flock and control areas, we used a mixture of data from a widely known early study of the lockout laws by the NSW Bureau of Crime Statistics and Research - the BOCSAR report (Menéndez et al., 2015) as well as anecdotal evidence from the national and local media. The areas identified in the media articles are largely consistent with the data from the BOCSAR report. The BOCSAR report includes Bondi and Coogee as displacement areas, but we exclude these two suburbs because their beachside demographics are substantially different from the inner-city suburbs in the "flock" group. Bondi and Coogee are excluded also because our analysis is based on the postcode level data, and the postcodes for Bondi and Coogee include rather large suburban areas of North Bondi and South Coogee. The addition of Erskineville is motivated by the relocation of a popular entertainment venue, The Spice Cellar, from Martin Place to Erskineville (Milton, 2015). Similarly, Waterloo is added because of the recent death of a man as a result of a coward punch (Levy, 2015).

\section{[ Insert Table 1 Here - The Flock Areas ]}

To evaluate the causal effect of the lockout laws, we compare the median weekly rent in the flock areas with that of the control areas, which have no major nightlife economy but are otherwise similar to the flock areas. The control group consists of postcode areas within eight kilometres of the CBD. We use this radius criterion because postcode areas outside the $8 \mathrm{~km}$ radius are likely to have substantially different demographics to the flock group. Although the $8 \mathrm{~km}$ radius is an arbitrary decision, we argue that it gives a control group of inner-city and surrounding suburbs 
that have a time trend similar to the flock group. For example, the $8 \mathrm{~km}$ criterion excludes suburbs in the Northern Beaches, which have beachside demographics, and Chatswood, which can be regarded as having its own business district. Postcodes within a certain radius are found using FreeMapTools, ${ }^{3}$ and verified manually by Google Maps to ensure that the average distance from the CBD to suburbs within a specific postcode area is calculated accurately. We apply the same procedure to adjacent postcodes to ensure that no postcode is wrongfully omitted or included. The mean of the distance of the suburbs within a postcode from the CBD is also added to the dataset as a control variable.

The postcodes of the lockout and other CBD areas (the SED areas) are excluded for the purpose of focusing the analysis on our main interest - the effect of the flock phenomenon, rather than the direct impact of the lockout itself on the regulated areas. Furthermore, those lockout areas have substantially higher rental prices than the areas in our treatment and control groups. Postcode 2026, which denotes Bondi, is also excluded from the control group, as noted above, due to its unique beachside characteristics. Figure 1 shows a map of the flock, lockout, and control areas. For the complete postcode list, see Table A1 in the Appendix.

An ideal, more subjective approach to designing treatment and control groups would be to classify them based on distance between each rental property and its nearest nightlife venue. We do not take this approach because the exact location and rental price of each property and the comprehensive list of nightlife venues and their locations are not readily available. We thus use a mixture of data from early studies and anecdotal evidence from the media, but the subjective nature of this approach leads to a concern

\footnotetext{
${ }^{3}$ www.freemaptools.com
} 
about potential estimation bias due to misclassification. To address this concern, we conduct a series of robustness tests and confirm the robustness of the main results.

[ Insert Figure 1 Here - Flock, Control, and Lockout Postcodes ]

In our analysis, a postcode area in a given quarter comprises the unit of observation. Table 2 reports the summary statistics of median weekly rent by bedroom type and treatment status. The mean of median weekly rents is calculated across postcode areas in the period from June 2013 to December 2015. The first column confirms that the weekly rent increases with the number of bedrooms. The last category -4+ bedroom dwellings - has considerably less observations than dwellings with fewer bedrooms because of the small number of bond lodgements for larger inner-city rental dwellings. The next two columns show that approximately $16 \%$ of our observations are from the flock (treatment) group. There is no significant difference in the average rent between the flock and control groups. The average rent of the 4+ bedroom type in the flock group is considerably lower than that of the control group, but the number of observations in the 4+ bedroom type is small and the standard deviations are large. This difference is smaller when median is used instead of mean across postcode-periods.

\section{[ Insert Table 2 Here - Summary Statistics of Median Weekly Rent ]}

The three panels in Figure 2 illustrate time trends in weekly rent by bedroom type. Each panel shows the time trends of the flock and control areas. The time trend of the lockout group is also shown for comparison. The three time series data in each panel show reasonably similar fluctuations before the implementation of the lockout laws in the March 2014 quarter. After the implementation of the laws, there is a noticeable plummet in the rent for one-bedroom dwellings in the treatment group for the 
September 2014 quarter, which appears to be a short-run effect of the lockout laws. This drop in one-bedroom rent around the September 2014 quarter is the only easily noticeable trend diversion following the implementation of the lockout laws, whereas no such effect is observed in larger dwellings, and the effect on one-bedroom dwellings appears to be short-lived, since it shows recovery shortly afterwards. Our extensive search identifies no other explanation for the rent plummet. In fact, the timing of the rent plummet coincides with rising rental rates and substantially low vacancy rates in the Sydney market (Wilson, 2014).

\section{[ Insert Figure 2 Here - Trends in Weekly Rent ]}

\subsection{Area Characteristics}

In the regression analysis, we use area characteristics to control for factors specific to each postcode area. Table 3 lists the area variables with their definitions as well as summary statistics for the treatment and control groups. The distance from the CBD is obtained as explained in the previous subsection. The percentage of renters, the percentage of single-person households, the average number of children, median age, and median weekly household income for each postcode area are collected from the 2011 Census. The number of schools is cumulatively added for all suburbs contained in the postcode based on information collected from the My School website. ${ }^{4}$

\section{[ Insert Table 3 Here - Area Characteristics Variables ]}

Table 3 profiles the flock and control groups, as well as the statistical difference between the two groups in the last column. The postcode areas in the control group tend

\footnotetext{
${ }^{4}$ www.myschool.edu.au
} 
to be farther from the CBD, have fewer renters and more families than the flock areas. There is no statistically significant difference in the other characteristic variables. The DID approach allows for systematic difference between the treatment and control groups, and we can obtain an unbiased estimate of the causal effect as long as the two groups follow the same time trend without the treatment, which is reasonably supported by Figure 2 . Nevertheless, the common trend assumption is generally more plausible if the treatment and control groups are similar, and the fact that our flock and control areas show no statistically significant difference in the median age and median income supports our econometric setup. We also conduct a number of sensitivity analyses in Section 6 to confirm that our results are robust over the selection of the two groups and not driven by a peculiar nature of data or a particular time point/postcode. Furthermore, our thorough background investigation identifies no major area-specific external shocks or policy changes during our sample period that may cause differential trends in weekly rents across the areas and thereby bias our DID estimates.

\subsection{Difference-In-Difference Approach}

We start our econometric analysis with a simple linear regression model, as a benchmark, that compares the flock and control groups after the implementation of the lockout laws. In this simple model (ex post OLS), the median weekly rent of postcode area $i$ in quarter $t$, which we denote MedWeeklyRent ${ }_{i t}$, is explained by

$$
\text { MedWeeklyRent }_{i t}=\alpha \text { Flock }_{i}+X_{i} \beta+\sum_{j=\operatorname{Sep} 14}^{\text {Dec15 }} \tau_{j} I[t=j]+\epsilon_{i t},
$$

where $F$ lock $_{i}$ is an indicator variable for the postcodes in the flock group, $X_{i}$ is a vector of the other area characteristics variables, $I[t=j]$ is an indicator function for quarter $j$, 
$\left(\alpha, \beta, \tau_{\operatorname{Sep} 14}, \ldots, \tau_{\text {Dec } 15}\right)$ is a set of parameters to be estimated, and $\epsilon_{i t}$ is an error term. Data from June 2014 to December 2015 quarters are used in this regression, with June 2014 being the reference period. The inclusion of the quarter dummies is important because the strong demand for housing since 2012 has led to a steadily increasing trend in rental prices Sydney-wide (Wilson, 2014). We have also attempted median rent in the $\log$ for the dependent variable, but the results are similar, with slightly worse fit than the non- $\log$ results.

The parameter of interest in Equation (1) is $\alpha$. However, it is unlikely to yield an unbiased estimate of the causal effect of the flock phenomenon because the flock areas are not identical to the control areas even without the lockout laws, and the estimator is thus plagued by a number of confounding factors that cannot be fully captured by the limited number of area characteristics variables we have in (1) (e.g., see Breen et al., 2011, for the potential relationship between alcohol-related crime and community characteristics). By the same token, the comparison between the weekly rents in flock areas for the periods before and after the lockout laws does not produce a reliable causal estimate because it is also biased by confounding time trends in crime (Leung et al., 2015) and trends in the housing market (Wilson, 2014). To obtain credible estimates, we rely on a quasi-experimental research design in which the following DID model is applied to the sample that contains both pre- and post-periods (June 2013 to December 2015 without March 2014):

$$
\begin{aligned}
& \text { MedWeeklyRent }_{i t} \\
& \qquad=\alpha \text { Flock }_{i}+\delta \text { Flock }_{i} * \text { Post }_{t}+\sum_{j=S e p 13}^{\text {Dec } 15} \tau_{j} I[t=j]+\epsilon_{i t},
\end{aligned}
$$


where Post $_{t}$ is an indicator variable for the quarter periods after the implementation of the lockout laws, and $\delta$ is the parameter of interest, which gives us the causal estimate of the flock phenomenon. We also estimate two variants of (2): one that includes $X_{i} \beta$, and one that includes postcode fixed effects. These two refinements attempt to control for the time-invariant characteristics of each area for a potentially better statistical inference, although there is a possibility that including additional controls adds irrelevant parameters and reduces statistical efficiency. Hence, there is no clear order among the three DID specifications, but they all provide unbiased causal estimates of the flock phenomenon as long as the common trend assumption is satisfied.

\section{Results}

\subsection{Overall Effect}

We first report the regression results of the pooled dataset, which includes all the observations of dwellings with $1,2,3$, and $4+$ bedrooms. Table 4 shows the results of the four regression models: [1] ex post OLS, [2] DID with no controls, [3] DID with controls, and [4] DID with fixed effects. Model [1] is based on a smaller number of observations than the other models because it only uses the time points after the implementation of the laws. Because the median rents are likely to be correlated across dwelling types and over time, statistical inference in all regressions is based on standard errors robust to heteroscedasticity and postcode-level clustering. ${ }^{5}$

Overall, the control variables exhibit reasonable coefficient estimates. Weekly rents increase with the number of bedrooms, the proximity to the CBD, and the median household income in the area. The positive and significant coefficients on the

\footnotetext{
${ }^{5}$ Bertrand et al. (2004) examine the credibility of difference-in-difference estimates and report that the clustering approach tends to yield desirable results in broader settings than other methods they test.
} 
percentages of renters and singles reflect a relatively large demand for rental properties for these demographics. The number of children has a positive and significant coefficient, which probably reflects the demand for relatively large dwellings. The number of schools per 1,000 population exhibits a negative and significant coefficient, probably because schools are more likely to be located in areas with lower land prices. The estimated coefficients on the quarter dummies are consistent with the housing market boom in Sydney (Wilson, 2014). Adding area characteristics to the regression increases $R$-squared from 0.739 in Model [2] to 0.814 in Model [3].

\section{[ Insert Table 4 Here - Effect of Lockout Laws - Overall Effect ]}

While these regression models show satisfying goodness of fit and coefficient estimates with statistical significance and expected signs, the impact of the flock phenomenon is not evident in all the models. Model [1] indicates that rents in the flock areas after the lockout laws are lower by $\$ 29.87$ than in the control areas, whereas the three DID estimates are positive, attributing an increase of $\$ 15.73$ to $\$ 20.53$ in weekly rents to the causal effect of the flock phenomenon. However, all these estimates lack statistical significance.

\subsection{Heterogeneity by Bedroom Type}

The results discussed in Subsection 5.1 are derived from data that pool all types of dwellings and are appropriate only when similar magnitudes of causal effect for all bedroom types are assumed, or when we are only interested in the average causal effect over all bedroom types. In reality, renters of small houses and large houses may have substantially different preferences, hence the magnitude of the causal effect may differ by bedroom type. To address this concern, we conduct a sub-sample analysis in which 
we repeat the same set of regression models for the sample of different bedroom types. Table 5 summarises the results, with four panels dedicated to four bedroom types. We do not estimate the model solely for the $4+$ bedroom type because the number of observations in this category is small, and we instead combine 3 bedroom and 4+ bedroom data in Panel (D). The full results are reported in the Appendix.

\section{[ Insert Table 5 Here - Effect of Lockout Laws - By Bedroom Type ]}

The results in Table 5 reveal a clear contrast across bedroom types. The DID estimates for one-bedroom dwellings, which are $10 \%$ or nearly $10 \%$ significant, indicate a small, negative causal effect of the flock phenomenon. No statistically significant causal effect is found in the results for 2 bedroom dwellings. In sharp contrast with these results, the DID estimates for the 3 bedroom and $3+$ bedroom dwellings are positive and highly significant. For example, the three DID models in Panel (C) indicate that the flock phenomenon has increased the weekly rent of 3 bedroom dwellings by approximately twenty dollars. The observed heterogeneous effect explains why no significant effect is found in the analysis of the overall sample in Table 4, where the negative effect of one-bedroom dwellings and the positive effect of $3+$ bedroom dwellings counteract each other.

\section{Robustness of Results}

To confirm the credibility of the results, we estimate variants of DID regressions as robustness tests. Table 6 reports their DID estimates (the estimated coefficients on Flock*Post). In the first test conducted, we repeat the same analysis using the period from June 2013 to December 2014, instead of June 2013 to December 2015. This is motivated by the speculation that there might be a short-run effect and a long-run effect 
of the lockout laws. The results in Panel (A) of Table 6 show that the negative DID estimates for one-bedroom dwellings are larger and more significant than were previously obtained and that the positive DID estimates for 3 and $3+$ bedroom types are smaller and less significant. This finding is consistent with the aforementioned observations from Figure 2, indicating that the negative impact of the flock phenomenon was only short-run and outweighed by the positive effect for larger houses, which remained after the first several quarters. Nevertheless, the contrast between the negative effect for the one-bedroom group and the positive effect for the $3+$ bedroom group is still evident in this short-term analysis.

\section{[ Insert Table 6 Here - Robustness of DID Regression Results ]}

We then repeat the regression analysis, altering the set of treatment and control postcodes. First, we conduct the analysis in which the control group is restricted to postcode areas whose centroid is within six kilometres of the CBD, instead of the initial eight kilometres. This is motivated by the fact that, as shown in Table 3, the original control areas are on average two kilometres farther from the CBD than the flock areas. When we impose the $6 \mathrm{~km}$ restriction, the number of control postcode areas reduces from 35 to 17, and the statistical differences in area characteristics between the control and treatment areas become less significant. The results shown in Panel (B) of Table 6 confirm the robustness of our results. The DID estimates exhibit lower statistical significance than previously, but this is mainly due to the loss of observations in the control group. Nevertheless, the signs of the DID estimates are consistent with the results in Table 5 and the magnitudes tend to be even larger.

Panels $(\mathrm{C}-1)$ to $(\mathrm{C}-6)$ show the results of robustness tests in which we repeatedly move each of the six treatment group postcodes to the control group. We conduct this 
analysis because the classification of the treatment and control groups is somewhat subjective partly based on media coverage and anecdotal evidence, hence misclassification is possible. These robustness tests are also useful in checking whether our results are driven by one particular postcode. The results of this test further highlight the robustness of our main results. Although the magnitudes of the DID estimates and their statistical significance vary across the different sets of treatment postcodes, all six experiments show a consistent pattern: there is weak evidence for a negative effect for one-bedroom dwellings and a positive, statistically significant effect for 3 and $3+$ bedroom dwellings.

\section{Discussion and Conclusion}

In this paper, we studied the causal effect of the flock phenomenon of the Sydney lockout laws on rental prices by applying a difference-in-difference (DID) approach to postcode-level weekly rent data. Although the overall effect models find no statistically significant causal effect, sub-sample analysis reveals differential causal effects: a negative effect on one-bedroom dwellings and a positive effect on $3+$ bedroom dwellings. The former effect is short-lived, while the latter is persistent, hence the positive effect on the flock areas appears to dominate in the long run. These opposite effects offset each other and consequently result in the insignificant estimate in the overall effect models. This pattern is found to be robust across alternative specifications.

Why has the flock phenomenon led to differential effects? We speculate that these differential effects have arisen from the geographical heterogeneity of dwellings of different sizes. Our analysis is at the postcode level, which is not very finely defined: our sample postcodes have a population of 13,300 on average. Consequently, the area 
inside each postcode may not be geographically homogeneous, hence our conjecture is that one-bedroom dwellings (typically units in an apartment building) tend to be close to main bars and entertainment strips, whereas dwellings with $3+$ bedrooms (typically houses) tend to be in a quiet part of the postcode. If that is the case, the increase in alcohol-fuelled risk, together with street noise and feelings of unsafety, is more salient to renters of one-bedroom dwellings, whereas the benefit of having a bustling entertainment strip within walking distance outweighs the disadvantages for renters of dwellings with $3+$ bedrooms.

Another possible explanation lies in the dissimilar demographics of different size dwellings. In particular, there is a high possibility that dwellings with $3+$ bedrooms for rent in flock areas are share-houses due to the likely demographic of the occupants and the proximity of the dwellings to universities and other types of educational institutions. As students generally have low incomes, shared housing (usually a dwelling with three or more bedrooms) may be more economical than renting a smaller dwelling alone. The increase in nightlife in these flock areas is now an added drawcard for students and may have increased the demand for larger dwellings in these areas. There may be other explanations. Identifying the true mechanism behind the heterogeneous effect is left for future research.

Our results highlight the importance of potential heterogeneity in the effect of geographical alcohol control policies. Our results also highlight heterogeneity in the time dimension and show contrasting short-run and long-run effects.

Our causal estimates may be biased due to the general equilibrium effect, that is, the possibility that renters move between the flock areas and the control areas and the demand of new renters for housing equilibrates between the flock areas and the control 
areas. This equilibrium effect affects our estimates not only by changing the rental prices in the treatment group but also by changing the rental prices in the control group in the opposite direction. Our estimates may therefore overstate the true causal effect; however, this general equilibrium effect may be of secondary importance, and it does not affect the direction of our causal estimates.

Some of the displacement areas, such as Newtown and Enmore, are currently under consideration for the introduction of self-imposed 3:00 am lockout laws (Koziol, 2015). The lockout laws have also been considered repeatedly in Melbourne (Yahoo7, 2016) since the city adopted the laws in 2008 and abandoned the trail three months later (Brook, 2016). The state of Queensland has recently announced the lockout laws to be implemented from 1 February 2017 (Queensland Government, 2016). While the introduction of the lockout laws is likely to improve safety in these areas, its possible impact on neighbouring districts requires careful examination. The dual effect of the lockout laws we find in this paper suggests that well-designed geographically targeted alcohol control can be a cost-effective approach even when crime displacement is taken into consideration, because the Sydney lockout laws have resulted in the relocation of not only violence and crime but also nightlife entertainment hubs. The negative impact is weak and short-lived, whereas the positive effect appears to be relatively large and persistent. Our results are consistent with the report by Donnelly et al. (2016) and the evidence in the literature (Guerette and Bowers, 2009; Bowers et al., 2011; Johnson et al., 2012; Telep et al., 2014), which consistently reveals that the amount of crime displaced is far less than the amount of crime prevented in the target areas. Research also suggests a possible "diffusion of crime control benefits" to surrounding areas (Clarke and Weisburd, 1994; Bowers et al., 2011). At the same time, our finding of the 
negative flock effect on small dwellings suggests that effective transitional crime prevention in displacement areas can further enhance the social value of geographical crime policies. 


\section{References}

Allen Consulting Group (2012) The Cumulative Impact of Licensed Premises in NSWPhase 1 Report, report to the NSW Office of Liquor Gaming \& Racing, last accessed 11 August 2016, <http://www.acilallen.com.au/cms_files/AllenConsulting_OLGRPhase1.pdf>.

Bertrand, M., Duflo, E., and Mullainathan, S. (2004) "How Much Should We Trust Differences-In-Differences Estimates," Quarterly Journal of Economics, 119(1), 249275.

Bianchi, C. (2015) The Winners and Losers of Sydney's Inner-City Lock-Out Laws, Domain Group, 27 September, last accessed 11 July 2016, <www.domain.com.au/news/the-winners- and-losers-of-sydneys-innercity-lockoutlaws-20150915-gjmrbd/>.

Biderman, C., de Mello, J.M.P., and Schneider, A. (2010) "Dry Laws and Homicides: Evidence from the São Paulo Metropolitan Area," Economic Journal, 120(543), 157182.

Bowers, K.J., Johnson, S.D., Guerette, R.T., Summers, L., and Poynton, S. (2011) "Spatial Displacement and Diffusion of Benefits Among Geographically Focused Policing Initiatives: A Meta-Analytical Review," Journal of Experimental Criminology, 7(4), 347-374.

Braga, A.A., Papachristos, A.V., and Hureau, D.M. (2014) "The Effects of Hot Spots Policing on Crime: An Updated Systematic Review and Meta-Analysis. Justice Quarterly, 31(4), 633-663.

Breen, C., Shakeshaft, A., Slade, T., Love, S., D’Este, C., and Mattick, R.P. (2011) "Do Community Characteristics Predict Alcohol-Related Crime?" Alcohol and Alcoholism, 46(4), 464-470.

Brook, B. (2016) Melbourne Lockout Laws Were Dumped in Months, While Brisbane Looks to Trial Laws Modelled on Sydney, www.new.com.au, 9 February, last accessed 11 August 2016, < http://www.news.com.au/national/victoria/melbourne-lockout-lawswere-dumped-in-months-while-brisbane-looks-to-trial-laws-modelled-on-sydney/newsstory/a9cc8c08180aed70d8523dc0aba70e36>

Clarke, R.V. and Weisburd, D. (1994) "Diffusion of Crime Control Benefits:

Observations on the Reverse of Displacement," in: R.V. Clarke (Ed.), Crime Prevention Studies, Vol. 2. Monsey: Criminal Justice Press, pp. 165-184.

Cullen, J.B., and Levitt, S.D. (1999) "Crime, Urban Flight, and the Consequences for Cities," Review of Economics and Statistics, 81(2), 159-169.

De Goeij, M.C.M., Veldhuizen, E.M., Buster, M.C.A., and Kunst, A.E. (2015) "The Impact of Extended Closing Times of Alcohol Outlets on Alcohol-Related Injuries in 
the Nightlife Areas of Amsterdam: A Controlled Before-And-After Evaluation," Addiction, 110(6), 955-964.

Donnelly, N., Weatherburn, D., Routledge, K., Ramsey, S., and Mahoney, N. (2016) "Did the 'Lockout Law' Reforms Increase Assaults at The Star Casino, Pyrmont?" Bureau Brief, No. 114, BOCSAR, Sydney.

Douglas, M. (1998) "Restriction of the Hours of Sale of Alcohol in a Small Community: A Beneficial Impact," Australian and New Zealand Journal of Public Health, 22(6), 714-719.

Dubin, R.A. and Goodman, A.C. (1982) "Valuation of Education and Crime Neighborhood Characteristics through Hedonic Housing Prices," Population and Environment, 5(3), 166-181.

Fischer, B., Turnbull, S., Poland, B., and Haydon, E. (2004) "Drug Use, Risk and Urban Order: Examining Supervised Injection Sites (SISs) as 'Governmentality'," International Journal of Drug Policy, 15(5), 357-365.

Fulde, G.W., Smith, M., and Forster, S.L. (2015) "Presentations with Alcohol-Related Serious Injury to a Major Sydney Trauma Hospital after 2014 Changes to Liquor Laws," Medical Journal of Australia, 203(9), 366.

Grönqvist, P., and Niknami, S. (2014) "Alcohol Availability and Crime: Lessons from Liberalized Weekend Sales Restrictions," Journal of Urban Economics, 81, 77-84.

Guerette, R.T., and Bowers, K.J. (2009) "Assessing the Extent of Crime Displacement and Diffusion of Benefits: A Review of Situational Crime Prevention Evaluations," Criminology, 47, 1331-1368.

Heaton, P. (2012) "Sunday Liquor Laws and Crime," Journal of Public Economics, 96(1-2), 42-52.

Ihlanfeldt, K., and Mayock, T. (2010) "Panel Data Estimates of the Effects of Different Types of Crime on Housing Prices," Regional Science and Urban Economics, 40(2), 161-172.

Johnson, S.D., Guerette, R.T., and Bowers, K.J. (2012) "Crime Displacement and Diffusion of Benefits," in: B.C. Welsh \& D.P. Farrington (Eds.), The Oxford Handbook of Crime Prevention, New York: Oxford University Press, pp. 337-353.

Klimova, A., and Lee, A.D. (2014) "Does a Nearby Murder Affect Housing Prices and Rents? The Case of Sydney," Economic Record, 90(s1), 16-40.

Koziol, C. (2015) "Newtown Bars to Trial 3am Lockout and Shots Ban," Sydney Morning Herald, 31 July, last accessed 12 July 2016, <www.smh.com.au/nsw/newtown-bars-to-trial-3am- lockout-and-shots-ban-20150731giomj5.html>. 
Kypri, K., Jones, C., McElduff, P., and Barker, D. (2011) "Effects of Restricting Pub Closing Times on Night-Time Assaults in an Australian City," Addiction,106(2), 303310 .

Leung, K., Ringland, C., Salmon, A., Chessman, J., and Muscatello, D. (2015) “That's Entertainment: Trends in Late-Night Assaults and Acute Alcohol Illness in Sydney's Entertainment Precinct," Contemporary Issues in Crime and Justice, 185(August), BOCSAR, Sydney.

Levy, M. (2015) "Man Dies in Hospital after Assault at Grosvenor Hotel in Waterloo," Sydney Morning Herald, 7 October, last accessed 10 July, 2015, $<$ www.smh.com.au/nsw/man-dies-in- hospital-after-assault-at-grosvenor-hotel-inwaterloo-20151006-gk2xty.html>.

Linden, L., and Rockoff, J.E. (2008) "Estimates of the Impact of Crime Risk on Property Values from Megan's Laws,” American Economic Review, 98(3), 1103-1127.

Manning, M., Fleming, C.M., and Ambrey, C.L. (2015) "Life Satisfaction and Individual Willingness to Pay for Crime Reduction," Regional Studies, DOI: 10.1080/00343404.2015.1082030.

Mazerolle, L., White, G., Ransley, J., and Ferguson, P. (2012) "Violence in and around Entertainment Districts: A Longitudinal Analysis of the Impact of Late-Night Lockout Legislation," Law \& Policy, 34(1), 55-79.

Menéndez, P., Weatherburn, D., Kypri, K., and Fitzgerald, J. (2015) "Lockouts and Last Drinks: The Impact of the January 2014 Liquor Licence Reforms on Assaults in NSW, Australia," Contemporary Issues in Crime and Justice, 183(revised April), BOCSAR, Sydney.

Miller, P., Droste, N., de Groot, F., Palmer, D., Tindall, J., Busija, L., Hyder, S., Gilham, K., and Wiggers, J. (2016) "Correlates and Motives of Pre-Drinking with Intoxication and Harm around Licensed Venues in Two Cities," Drug and Alcohol Review, 35(2), 177-186.

Milton, K. (2015) The End is Near: Lockout Laws Follow The Spice Cellar to Erskineville, Broadsheet, 2 July, last accessed 11 July 2016,

<www.broadsheet.com.au/sydney/nightlife/article/end-near>.

NSW Government 2014, New Alcohol Laws now in Place, last accessed 10 July 2016, <www.nsw.gov.au/newlaws> and <www.nsw.gov.au/sites/default/files/promos/alcohol_and_drug_fuelled_violence_initiat ives_-_feb_2014.pdf>.

NSW Government: Fair Trading (2014) Rental Bond Board Annual Report: 201213, NSW Fair Trading, Sydney, last accessed 11 July 
2016, <http://www.fairtrading.nsw.gov.au/biz_res/ftweb/pdfs/About_us/Publications/A nnual_reports/RBB_annual_report_1213.pdf >

NSW Government: Family \& Community Services (2015) Rent and Sales Reports Overview, last accessed 11 July 2016, <http://www.housing.nsw.gov.au/aboutus/reports-plans-and-papers>.

Queensland Government (2016) Late Trading and lam Lock Out, last accessed 11 August 2016, < https://www.business.qld.gov.au/industry/liquorgaming/liquor/compliance-licensees/trading-hours/late-trading $>$

Ralston, N. (2015) "Maps Show Changing Nature of Violence in Sydney's CBD since Lock-Out Laws," Sydney Morning Herald, 21 August, last accessed 10 July 2016, $<$ http://www.smh.com.au/nsw/maps-show-changing-nature-of-violence-in-sydneys-cbdsince-lockout-laws-20150821-gj51uk.html>.

Rizzo, M.J. (1979) “The Cost of Crime to Victims: An Empirical Analysis," Journal of Legal Studies, 8(1), 177-205.

Spicer, D. (2015) "Hugo's Lounge in Sydney's Kings Cross Forced to Close After Revenue Drop, Owner Blames Lockout Laws," ABC News, 30 July, last accessed 10 July 2016, <www.abc.net.au/news/2015-07-30/hugos-kings-cross-to-close-blames-nswlockout- laws/6659340>.

Telep, C.W., Weisburd, D., Gill, C.E., Vitter, Z., and Teichman, D. (2014) "Displacement of Crime and Diffusion of Crime Control Benefits in Large-Scale Geographic Areas: A Systematic Review," Journal of Experimental Criminology,10(4), 515-548.

Tita, G.E., Petras, T.L., and Greenbaum, R.T. (2006) "Crime and Residential Choice: A Neighborhood Level Analysis of the Impact of Crime on Housing Prices," Journal of Quantitative Criminology, 22(4), 299-317.

Voas, R.B., Lange, J.E., and Johnson, M.B. (2002) "Reducing High-Risk Drinking by Young Americans South of the Border: The Impact of a Partial Ban on Sales of Alcohol," Journal of Studies on Alcohol, 63(3), 286-292.

Wilson, A. (2014) State of the Market Report-September 2014, Domain Group, Sydney, last accessed 12 July 2016, <http://www.domain.com.au/content/Files/apm/reports/TheDomainGroupStateoftheMar ket_SPRING_Sydney.pdf>

Yahoo7 (2016) Melb Won't Get Lockout Laws Like Sydney, Aug 8 2016, last accessed 11 August, 2016, < https://au.news.yahoo.com/vic/a/32268604/melb-wont-get-lockoutlaws-like-sydney/\#page1 > 
Table 1: The Flock Areas

Postcode Suburb

2009 Pyrmont and Darling Island

2016 Redfern

2017 Waterloo and Zetland

2037 Glebe, Harold Park and Forest Lodge

2042 Enmore and Newtown

2043 Erskineville 
Table 2: Summary Statistics of Median Weekly Rent

\begin{tabular}{lccc}
\hline MedianWeeklyRent (AU\$) & All sample areas & Flock areas & Control areas \\
\hline All types & & & \\
Mean & 703.7 & 702.4 & 703.9 \\
Standard deviation & $(262.7)$ & $(198.3)$ & $(273.1)$ \\
Number of observations & 1,223 & 193 & 1,030 \\
\hline (A) 1 bedroom dwellings & & & \\
Mean & 469.5 & 479.7 & 467.5 \\
Standard deviation & $(57.4)$ & $(62.7)$ & $(56.2)$ \\
Number of observations & 370 & 60 & 310 \\
\hline (B) 2 bedroom dwellings & & & \\
Mean & 629.7 & 672.5 & 622.1 \\
Standard deviation & $(75.2)$ & $(40.9)$ & $(77.4)$ \\
Number of observations & 399 & 60 & 339 \\
\hline (C) 3 bedroom dwellings & & & \\
Mean & 890.7 & 891.2 & 890.6 \\
Standard deviation & $(142.9)$ & $(87.5)$ & $(151.4)$ \\
$\quad$ Number of observations & 371 & 60 & 311 \\
\hline (D) 4+ bedroom dwellings & & & \\
Mean & $1,267.7$ & 997.5 & $1,317.9$ \\
Standard deviation & $(373.4)$ & $(196.9)$ & $(377.7)$ \\
$\quad$ Number of observations & 83 & 13 & 70 \\
\hline
\end{tabular}

Note: MedianWeeklyRent is the median weekly rental price of bonds lodged with the Renting and Strata Service Branch. Data are drawn from the period June 2013 - December 2015.

Table 3: Area Characteristics Variables

\begin{tabular}{|c|c|c|c|c|}
\hline $\begin{array}{l}\text { Characteristics } \\
\text { variables }\end{array}$ & Definition & $\begin{array}{l}\text { Mean: } \\
\text { Flock }\end{array}$ & $\begin{array}{l}\text { Mean: } \\
\text { Control }\end{array}$ & Difference \\
\hline $\mathrm{KmsCBD}$ & $\begin{array}{l}\text { The mean distance from the CBD }(\mathrm{km}) \text { of the } \\
\text { suburbs within the postcode }\end{array}$ & 3.75 & 5.80 & $-2.04 * * *$ \\
\hline$\%$ Renters & $\begin{array}{l}\text { The percentage of renters in the postcode } \\
\text { population }\end{array}$ & 58.87 & 43.53 & $15.34 * * *$ \\
\hline$\%$ Singles & $\begin{array}{l}\text { The percentage of single-person households in the } \\
\text { postcode population }\end{array}$ & 77.08 & 75.71 & 1.37 \\
\hline AvgNumChild & $\begin{array}{l}\text { The average number of children per household in } \\
\text { the postcode }\end{array}$ & 1.48 & 1.65 & $-0.16 * * *$ \\
\hline MedAge & The median age of the population of a postcode & 34.17 & 36.23 & -2.06 \\
\hline MedIncome & $\begin{array}{l}\text { The median weekly household income for the } \\
\text { postcode }\end{array}$ & 1,739 & 1,992 & -253 \\
\hline SchoolsPer1000 & $\begin{array}{l}\text { The number of schools per } 1,000 \text { people in the } \\
\text { postcode }\end{array}$ & 0.29 & 0.48 & -0.19 \\
\hline
\end{tabular}

Note: All variables are defined at the time of the 2011 Census. The numbers are based on 6 flock postcode areas and 41 control postcode areas. In the last column, the results of $t$ tests for the statistical difference between the two groups are reported by $* \mathrm{p}<0.1, * * \mathrm{p}<0.05$, *** $\mathrm{p}<0.01$. 
Table 4: Effect of Lockout Laws - Overall Effect

\begin{tabular}{|c|c|c|c|c|}
\hline $\begin{array}{l}\text { Dependent variable: } \\
\text { MedianWeeklyRent }\end{array}$ & $\begin{array}{l}\text { [1] Ex post } \\
\text { OLS }\end{array}$ & $\begin{array}{l}\text { [2] Dif-in-Dif } \\
\text { No Controls }\end{array}$ & $\begin{array}{l}\text { [3] Dif-in-Dif } \\
\text { w/ Controls }\end{array}$ & $\begin{array}{l}\text { [4] Dif-in-Dif } \\
\text { Fixed Effects }\end{array}$ \\
\hline Sample periods used & Jun14-Dec15 & Jun13-Dec15 & Jun13-Dec15 & Jun13-Dec15 \\
\hline \multicolumn{5}{|c|}{ Bedroom type (reference: one-bedroom) } \\
\hline 2 Bedroom & $\begin{array}{c}165.23 * * * \\
(8.32)\end{array}$ & $\begin{array}{c}160.58^{* * * *} \\
(7.41)\end{array}$ & $\begin{array}{c}160.10^{* * * *} \\
(8.10)\end{array}$ & $\begin{array}{c}161.52 * * * \\
(7.77)\end{array}$ \\
\hline 3 Bedroom & $\begin{array}{c}428.38 * * * \\
(18.11)\end{array}$ & $\begin{array}{l}421.83 * * * \\
(18.46)\end{array}$ & $\begin{array}{l}421.66 * * * \\
(17.92)\end{array}$ & $\begin{array}{l}421.14 * * * \\
(18.26)\end{array}$ \\
\hline 4+ Bedroom & $\begin{array}{l}819.13 * * * \\
(91.77)\end{array}$ & $\begin{array}{c}796.58 * * * \\
(104.71)\end{array}$ & $\begin{array}{l}800.10 * * * \\
(92.35)\end{array}$ & $\begin{array}{l}812.52 * * * \\
(91.35)\end{array}$ \\
\hline Flock & $\begin{array}{l}-29.87 \\
(29.57)\end{array}$ & $\begin{array}{l}-16.39 \\
(38.05)\end{array}$ & $\begin{array}{l}-46.11 \\
(35.01)\end{array}$ & \\
\hline Flock*Post (DID Estimator) & & $\begin{array}{c}20.53 \\
(15.45)\end{array}$ & $\begin{array}{c}15.73 \\
(15.43)\end{array}$ & $\begin{array}{l}16.86 \\
(15.24)\end{array}$ \\
\hline $\mathrm{KmsCBD}$ & $\begin{array}{c}-18.33 * * \\
(8.60)\end{array}$ & & $\begin{array}{c}-17.57^{*} \\
(8.72)\end{array}$ & \\
\hline$\%$ Renters & $\begin{array}{l}5.03 * * \\
(1.90)\end{array}$ & & $\begin{array}{l}4.82 * * \\
(1.83)\end{array}$ & \\
\hline$\%$ Singles & $\begin{array}{l}13.70^{*} \\
(7.25)\end{array}$ & & $\begin{array}{c}13.87 * * \\
(6.87)\end{array}$ & \\
\hline AvgNumChild & $\begin{array}{l}386.50 * * * \\
(98.96)\end{array}$ & & $\begin{array}{l}362.02 * * * \\
(93.01)\end{array}$ & \\
\hline MedAge & $\begin{array}{c}5.24 \\
(4.17)\end{array}$ & & $\begin{array}{c}4.46 \\
(3.92)\end{array}$ & \\
\hline MedIncome & $\begin{array}{l}0.15 * * * \\
(0.04)\end{array}$ & & $\begin{array}{l}0.15^{* * *} \\
(0.04)\end{array}$ & \\
\hline SchoolsPer1000 & $\begin{array}{c}-42.37 * * * \\
(12.37)\end{array}$ & & $\begin{array}{l}-45.19 * * * \\
(12.66)\end{array}$ & \\
\hline Sep13 & & $\begin{array}{l}-5.23 \\
(9.33)\end{array}$ & $\begin{array}{l}-5.37 \\
(9.24)\end{array}$ & $\begin{array}{l}-3.92 \\
(9.11)\end{array}$ \\
\hline Dec13 & & $\begin{array}{c}9.15 \\
(8.48)\end{array}$ & $\begin{array}{c}9.48 \\
(7.76)\end{array}$ & $\begin{array}{l}12.46 \\
(7.70)\end{array}$ \\
\hline Jun14 & & $\begin{array}{c}26.37 * * * \\
(8.98)\end{array}$ & $\begin{array}{l}29.46 * * * \\
(8.22)\end{array}$ & $\begin{array}{l}31.06 * * * \\
(8.12)\end{array}$ \\
\hline Sep14 & $\begin{array}{r}-12.46 \\
(8.69)\end{array}$ & $\begin{array}{l}12.42 * \\
(6.65)\end{array}$ & $\begin{array}{c}16.88^{* *} \\
(6.51)\end{array}$ & $\begin{array}{c}16.78^{* *} \\
(6.60)\end{array}$ \\
\hline Dec14 & $\begin{array}{l}-1.26 \\
(9.11)\end{array}$ & $\begin{array}{l}23.89 * * * \\
(7.13)\end{array}$ & $\begin{array}{c}28.00 * * * \\
(6.85)\end{array}$ & $\begin{array}{l}28.47 * * * \\
(6.58)\end{array}$ \\
\hline Mar15 & $\begin{array}{c}7.66 \\
(9.85)\end{array}$ & $\begin{array}{l}33.33 * * * \\
(9.59)\end{array}$ & $\begin{array}{l}37.70 * * * \\
(8.61)\end{array}$ & $\begin{array}{l}35.83 * * * \\
(7.96)\end{array}$ \\
\hline Jun15 & $\begin{array}{c}17.15^{* * *} \\
(8.44)\end{array}$ & $\begin{array}{c}45.02 * * * \\
(8.55)\end{array}$ & $\begin{array}{c}46.73 * * * \\
(7.97)\end{array}$ & $\begin{array}{c}48.78 * * * \\
(7.70)\end{array}$ \\
\hline Sep15 & $\begin{array}{c}4.74 \\
(10.89)\end{array}$ & $\begin{array}{c}28.00 * * * \\
(8.20)\end{array}$ & $\begin{array}{c}34.76 * * * \\
(8.42)\end{array}$ & $\begin{array}{c}33.22 * * * \\
(7.82)\end{array}$ \\
\hline Dec15 & $\begin{array}{c}34.50 * * * \\
(9.10)\end{array}$ & $\begin{array}{c}57.44 * * * \\
(8.48)\end{array}$ & $\begin{array}{c}64.06 * * * \\
(8.89)\end{array}$ & $\begin{array}{c}62.66^{* * * *} \\
(8.04)\end{array}$ \\
\hline Intercept & $\begin{array}{c}-1784.11^{* *} \\
(703.49) \\
\end{array}$ & $\begin{array}{r}446.49 \\
(10.36) \\
\end{array}$ & $\begin{array}{c}-1753.50 * * \\
(666.81) \\
\end{array}$ & \\
\hline$R^{2}$ & 0.821 & 0.739 & 0.814 & 0.832 \\
\hline$N$ & 857 & 1,223 & 1,223 & 1,223 \\
\hline
\end{tabular}

Note: Standard errors robust to heteroscedasticity and postcode clusters are in parentheses. For the fixedeffects regression [4], the within $R^{2}$ coefficient is reported.

$* \mathrm{p}<0.1, * * \mathrm{p}<0.05, * * * \mathrm{p}<0.01$. 
Table 5: Effect of Lockout Laws - By Bedroom Type

\begin{tabular}{|c|c|c|c|c|}
\hline $\begin{array}{l}\text { Dependent variable: } \\
\text { MedianWeeklyRent }\end{array}$ & [1] OLS & $\begin{array}{l}\text { [2] Dif-in-Dif } \\
\text { No Controls }\end{array}$ & $\begin{array}{l}\text { [3] Dif-in-Dif } \\
\text { w/ Controls }\end{array}$ & $\begin{array}{l}\text { [4] Dif-in-Dif } \\
\text { Fixed Effects }\end{array}$ \\
\hline Sample periods used & Jun14-Dec15 & Jun13-Dec15 & Jun13-Dec15 & Jun13-Dec15 \\
\hline \multicolumn{5}{|l|}{ (A) one-bedroom dwellings } \\
\hline Flock & $\begin{array}{l}-26.76 \\
(22.95)\end{array}$ & $\begin{array}{c}17.49 \\
(26.63)\end{array}$ & $\begin{array}{l}-17.96 \\
(22.74)\end{array}$ & \\
\hline Flock*Post (DID Estimator) & & $\begin{array}{l}-7.51 \\
(5.89)\end{array}$ & $\begin{array}{c}-11.45^{*} \\
(6.41)\end{array}$ & $\begin{array}{l}-9.89 \\
(5.94)\end{array}$ \\
\hline Period Dummies & YES & YES & YES & YES \\
\hline Other control variables & YES & & YES & \\
\hline Postcode fixed effects & & & & YES \\
\hline$R^{2}$ & 0.309 & 0.030 & 0.326 & 0.163 \\
\hline$N$ & 261 & 370 & 370 & 370 \\
\hline \multicolumn{5}{|l|}{ (B) 2 bedroom dwellings } \\
\hline Flock & $\begin{array}{l}-1.40 \\
(19.21)\end{array}$ & $\begin{array}{c}48.78 * * \\
(19.56)\end{array}$ & $\begin{array}{l}-5.38 \\
(19.98)\end{array}$ & \\
\hline Flock*Post (DID Estimator) & & $\begin{array}{c}2.14 \\
(8.74)\end{array}$ & $\begin{array}{c}1.74 \\
(8.75)\end{array}$ & $\begin{array}{c}2.67 \\
(8.51)\end{array}$ \\
\hline Period Dummies & YES & YES & YES & YES \\
\hline Other control variables & YES & & YES & \\
\hline Postcode fixed effects & & & & YES \\
\hline$R^{2}$ & 0.598 & 0.124 & 0.610 & 0.436 \\
\hline$N$ & 278 & 399 & 399 & 398 \\
\hline \multicolumn{5}{|l|}{ (C) 3 bedroom dwellings } \\
\hline Flock & $\begin{array}{l}-57.50 \\
(39.75)\end{array}$ & $\begin{array}{l}-15.60 \\
(39.89)\end{array}$ & $\begin{array}{l}-78.88^{*} \\
(40.73)\end{array}$ & \\
\hline Flock*Post (DID Estimator) & & $\begin{array}{c}22.57^{* *} \\
(10.21)\end{array}$ & $\begin{array}{c}19.45^{* * *} \\
(9.58)\end{array}$ & $\begin{array}{c}19.41 * * \\
(9.04)\end{array}$ \\
\hline Period Dummies & YES & YES & YES & YES \\
\hline Other control variables & YES & & YES & \\
\hline Postcode fixed effects & & & & YES \\
\hline$R^{2}$ & 0.623 & 0.034 & 0.648 & 0.210 \\
\hline$N$ & 257 & 371 & 371 & 371 \\
\hline \multicolumn{5}{|c|}{ (D) 3 and 4+ bedroom dwellings } \\
\hline 4+ Bedroom & $\begin{array}{l}355.38 * * * \\
(64.65)\end{array}$ & $\begin{array}{l}377.71 * * * \\
(98.38)\end{array}$ & $\begin{array}{l}363.90 * * * \\
(68.48)\end{array}$ & $\begin{array}{l}388.01 * * * \\
\quad(69.14)\end{array}$ \\
\hline Flock & $\begin{array}{l}-83.65 \\
(60.08)\end{array}$ & $\begin{array}{c}-119.07 * \\
(65.76)\end{array}$ & $\begin{array}{c}-127.81 * * \\
(61.44)\end{array}$ & \\
\hline Flock*Post (DID Estimator) & & $\begin{array}{c}78.68 * * * \\
(26.88)\end{array}$ & $\begin{array}{l}62.28 * * \\
(24.90)\end{array}$ & $\begin{array}{c}55.86^{* *} \\
(26.86)\end{array}$ \\
\hline Period Dummies & YES & YES & YES & YES \\
\hline Other control variables & YES & & YES & \\
\hline Postcode fixed effects & & & & YES \\
\hline$R^{2}$ & 0.650 & 0.363 & 0.662 & 0.581 \\
\hline$N$ & 355 & 469 & 469 & 469 \\
\hline
\end{tabular}

Note: Standard errors robust to heteroscedasticity and postcode clusters are in parentheses. For the fixedeffects regression [4], the within $R^{2}$ coefficient is reported.

$* \mathrm{p}<0.1, * * \mathrm{p}<0.05, * * * \mathrm{p}<0.01$. 
Table 6: Robustness of DID Regression Results

\begin{tabular}{lcccc}
\hline Dep.var.: MedianWeeklyRent & 1 Bedroom & 2 Bedroom & 3 Bedroom & 3+ Bedroom \\
\hline (A) Short-term effect (sample period Jun13-Dec14, instead of Jun13-Dec15) & \\
[2] DID No Controls & $-11.29^{*}$ & -1.30 & 12.74 & $46.30^{*}$ \\
& $(6.35)$ & $(8.67)$ & $(7.77)$ & $(24.63)$ \\
[3] DID with Controls & $-15.41^{* *}$ & -1.81 & 8.98 & 38.52 \\
& $(6.87)$ & $(8.84)$ & $(8.34)$ & $(23.13)$ \\
& $-14.23^{* *}$ & -1.60 & 7.92 & $49.58^{* *}$ \\
[4] DID with Fixed Effects & $(6.18)$ & $(8.65)$ & $(7.70)$ & $(23.25)$ \\
\hline (B) Excluding areas whose KmsCBD >= 6km & & & \\
[2] DID No Controls & -9.97 & 3.74 & $25.67^{*}$ & $80.67^{* *}$ \\
& $(6.94)$ & $(9.77)$ & $(14.70)$ & $(30.76)$ \\
[3] DID with Controls & $-14.47^{*}$ & 2.20 & $22.13^{*}$ & 42.56 \\
& $(8.27)$ & $(10.33)$ & $(12.55)$ & $(26.61)$ \\
[4] DID with Fixed Effects & -10.24 & 3.74 & $23.79^{*}$ & 34.38 \\
& $(6.99)$ & $(9.75)$ & $(11.82)$ & $(28.15)$ \\
\hline
\end{tabular}

(C-1) Moving Postcode 2009 (Pyrmont and Darling Island) from Flock to Control group
[2] DID No Controls
$-8.19$
4.41
$23.18 * *$
$83.12 * * *$
[3] DID with Controls
$-11.92$
4.07
$20.28^{*}$
$67.82 * *$
[4] DID with Fixed Effects
$-10.58$
4.98
$20.30 * *$
$62.74 * *$

(C-2) Moving Postcode 2016 (Redfern) from Flock to Control group
[2] DID No Controls
$-2.41$
0.47
$27.38 * * *$
$82.12 * * *$
[3] DID with Controls
$-5.84$
0.09
$24.25 * *$
$66.71 * *$
[4] DID with Fixed Effects
$-4.65$
1.01
$24.23 * * *$
$58.42 *$

(C-3) Moving Postcode 2017 (Waterloo and Zetland) from Flock to Control group
[2] DID No Controls
$-5.24$
6.07
$23.20^{* *}$
$85.26 * * *$
[3] DID with Controls
$-9.20$
5.71
$20.11^{*}$
$67.44 * *$
[4] DID with Fixed Effects
$-7.59$
6.62
$20.17 *$
$62.63^{* *}$

(C-4) Moving Postcode 2037 (Glebe, Harold Park, Forest Lodge) from Flock to Control group
[2] DID No Controls
$-10.56^{*}$
$-6.32$
$14.19^{*}$
$48.01 * *$
[3] DID with Controls
$-13.95 * *$
$-6.71$
11.24
$32.91 * *$
[4] DID with Fixed Effects
$-12.84 * *$
$-5.79$
11.12
21.77

(C-5) Moving Postcode 2042 (Enmore and Newtown) from Flock to Control group
[2] DID No Controls
$-9.52$
5.06
$21.42^{*}$
$18.28^{*}$
$69.58^{*}$
[3] DID with Controls
$-13.01 *$
4.67
$18.24 *$
54.90

(C-6) Moving Postcode 2043 (Erskineville) from Flock to Control group
[2] DID No Controls
$-7.63$
2.61
$21.89^{*}$
[3] DID with Controls
$-11.88$
2.25
$18.78^{*}$
$85.18 * * *$
[4] DID with Fixed Effects
$-10.00$
3.16
$18.79^{*}$
$68.22 * *$
$61.61 * *$

Note: The table reports the estimated coefficients on Flock*Post (the DID estimator). Standard errors robust to heteroscedasticity and postcode clusters are in parentheses.

$* \mathrm{p}<0.1, * * \mathrm{p}<0.05, * * * \mathrm{p}<0.01$. 
Figure 1: Flock, Control, and Lockout Postcodes

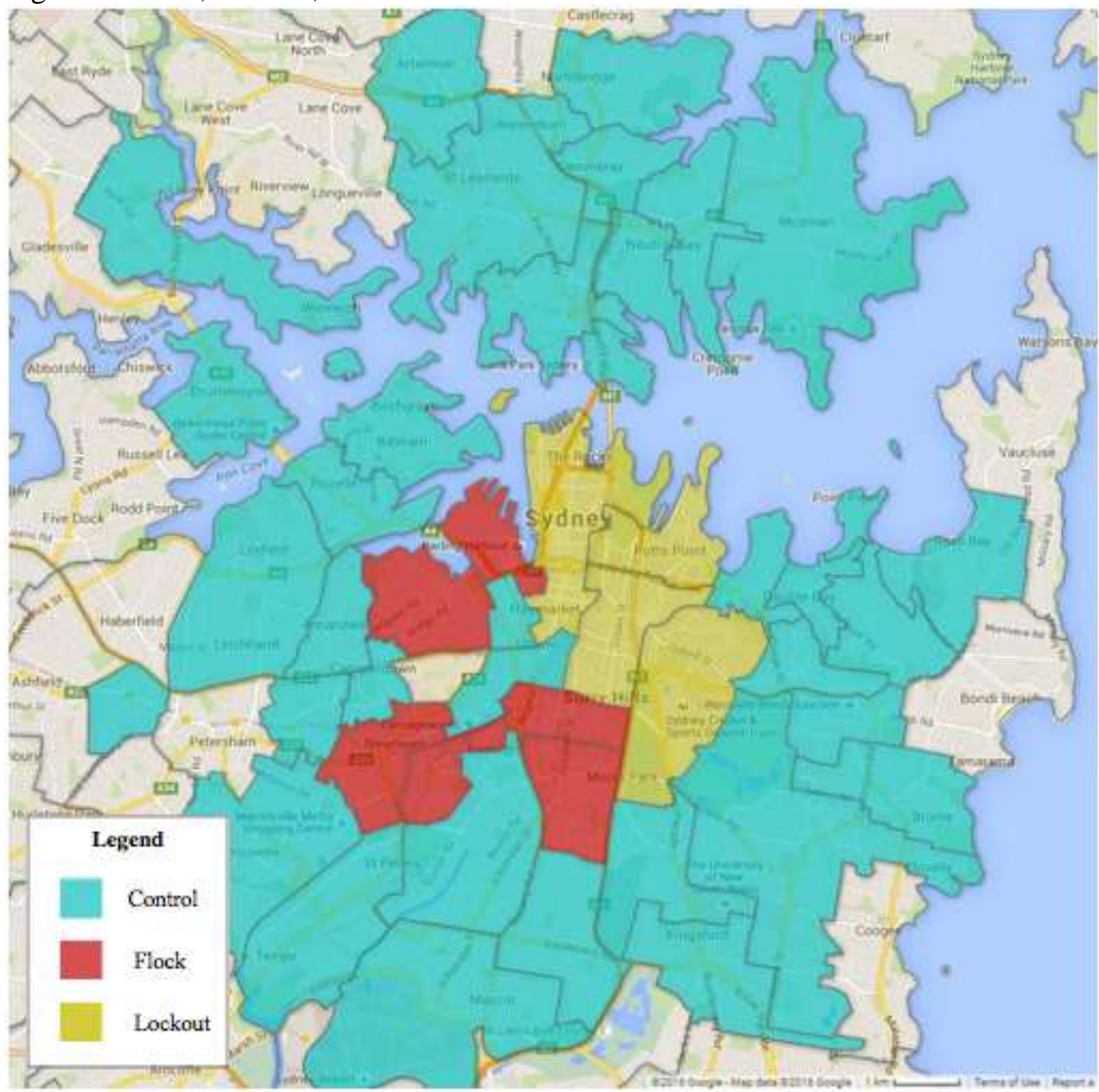

Note: The actual lockout area (the Kings Cross and CBD entertainment precincts) is smaller than the lockout postcodes shown in the figure. The difference arises because of the use of postcode level data in this paper. 
Figure 2: Trends in Weekly Rent

(A) One-bedroom dwellings

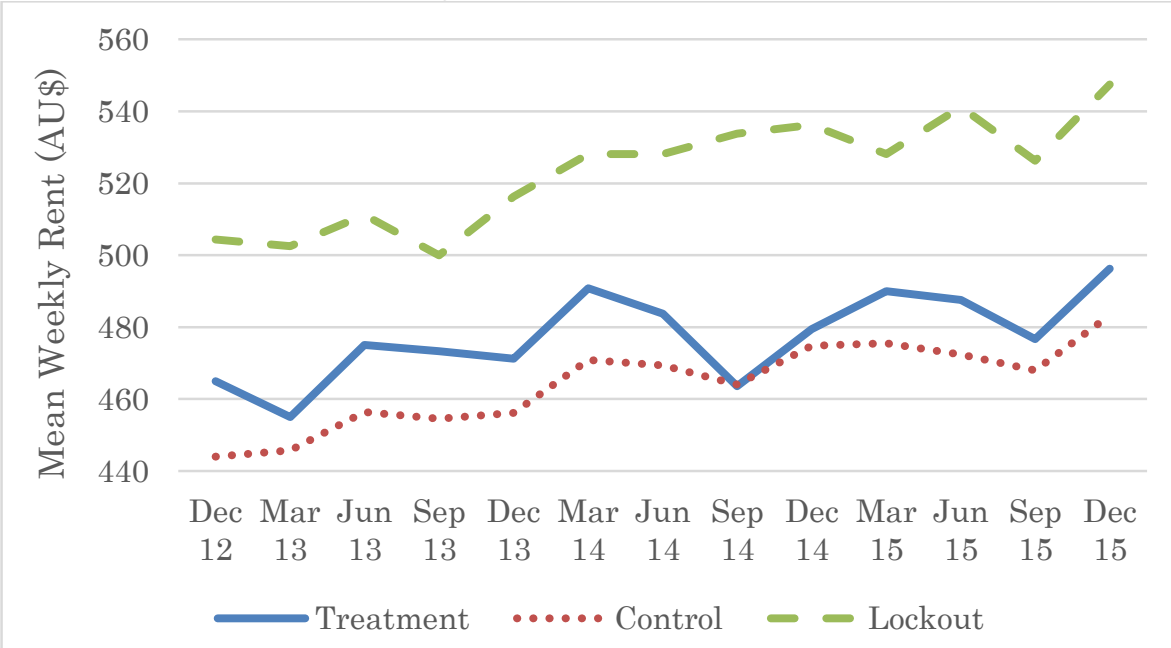

(B) 2 bedroom dwellings

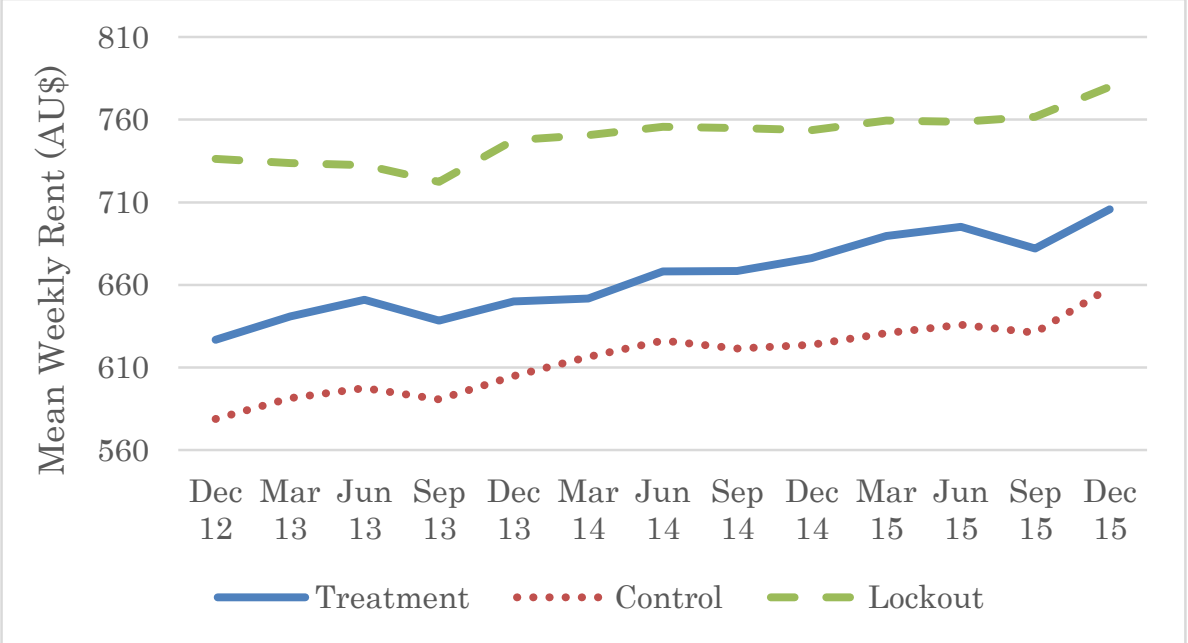

(C) 3 bedroom dwellings

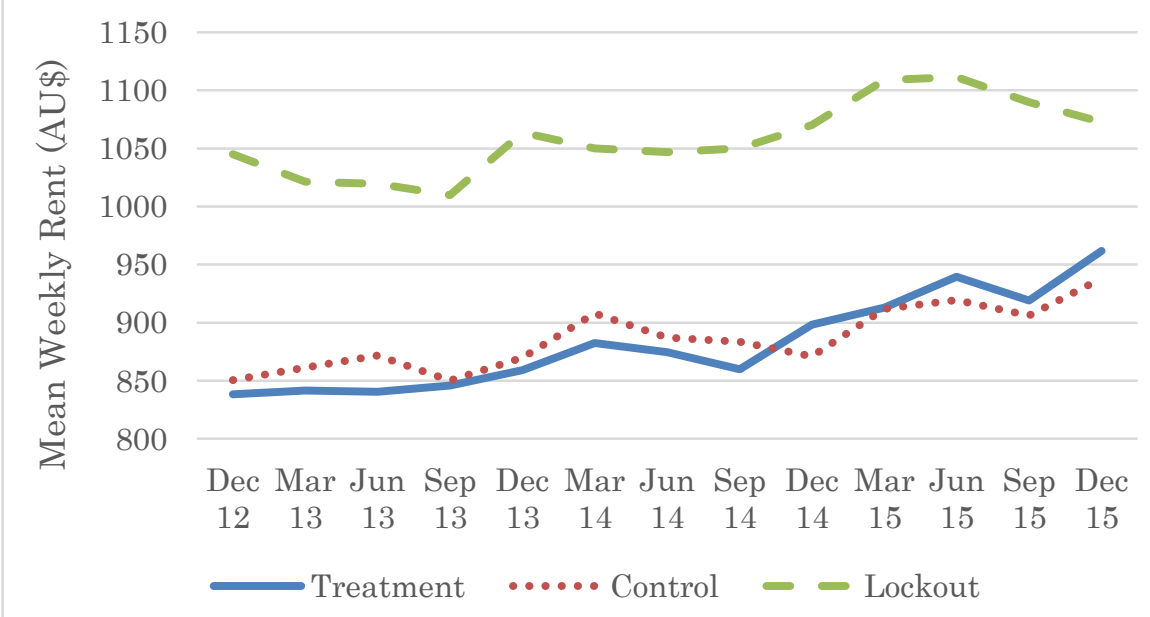

Note: The figures show time trends in the mean of the postcode-level median weekly rental price data for three groups: the displacement postcodes (Treatment), control postcodes (Control), and postcodes directly restricted by the lockout laws (Lockout). 


\section{Appendix}

Table A1: List of Postcode Areas Used in Analysis

\begin{tabular}{|c|c|c|}
\hline Postcode & Flock/Control/Lockout & Suburbs Represented by Postcode \\
\hline 2000 & Lockout & $\begin{array}{l}\text { Barangaroo, Darling Harbour, Dawes Point, Haymarket, Millers Point, } \\
\text { Parliament House, Sydney, Sydney South and The Rocks }\end{array}$ \\
\hline 2007 & Control & Ultimo \\
\hline 2008 & Control & Chippendale, Darlington, Golden Grove \\
\hline 2009 & Flock & Darling Island, Pyrmont \\
\hline 2010 & Lockout & Darlinghurst, Surry Hills and Taylor Square \\
\hline 2011 & Lockout & $\begin{array}{l}\text { Elizabeth Bay, HMAS Kuttabul, Kings Cross, Potts Point, Rushcutters } \\
\text { Bay and Woolloomooloo }\end{array}$ \\
\hline 2015 & Control & Alexandria, Beaconsfield, Eveleigh \\
\hline 2016 & Flock & Redfern \\
\hline 2017 & Flock & Waterloo, Zetland \\
\hline 2018 & Control & Eastlakes, Rosebery \\
\hline 2020 & Control & Mascot, Sydney Domestic Airport, Sydney International Airport \\
\hline 2021 & Lockout & Centennial Park, Moore Park and Paddington \\
\hline 2022 & Control & Bondi Junction, Bondi Junction Plaza, Queens Park \\
\hline 2023 & Control & Bellevue Hill \\
\hline 2024 & Control & Bronte, Charing Cross, Waverley \\
\hline 2025 & Control & Woollahra \\
\hline 2027 & Control & Darling Point, Edgecliff, HMAS Rushcutters, Point Piper \\
\hline 2028 & Control & Double Bay \\
\hline 2029 & Control & Rose Bay \\
\hline 2031 & Control & Clovelly, Clovelly West, Randwick, St Pauls \\
\hline 2032 & Control & Daceyville, Kingsford \\
\hline 2033 & Control & Kensington \\
\hline 2037 & Flock & Forest Lodge, Glebe \\
\hline 2038 & Control & Annandale \\
\hline 2039 & Control & Rozelle \\
\hline 2040 & Control & Leichhardt, Lilyfield \\
\hline 2041 & Control & Balmain, Balmain East, Birchgrove \\
\hline 2042 & Flock & Enmore, Newtown \\
\hline 2043 & Flock & Erskineville \\
\hline 2044 & Control & St Peters, Sydenham, Tempe \\
\hline 2047 & Control & Drummoyne \\
\hline 2048 & Control & Stanmore, Westgate \\
\hline 2050 & Control & Camperdown \\
\hline 2060 & Control & $\begin{array}{l}\text { HMAS Platypus, HMAS Waterhen, Lavender Bay, McMahons Point, } \\
\text { North Sydney, North Sydney Shopping World, Waverton }\end{array}$ \\
\hline 2061 & Control & Kirribilli, Milsons Point \\
\hline 2062 & Control & Cammeray \\
\hline 2063 & Control & Northbridge \\
\hline 2064 & Control & Artarmon \\
\hline 2065 & Control & $\begin{array}{l}\text { Crows Nest, Gore Hill, Greenwich, Naremburn, Royal North Shore } \\
\text { Hospital, St Leonards, Wollstonecraft }\end{array}$ \\
\hline 2088 & Control & Mosman \\
\hline 2089 & Control & Neutral Bay, Neutral Bay Junction \\
\hline 2090 & Control & Cremorne, Cremorne Point \\
\hline 2110 & Control & Hunters Hill, Hunters Hill West, Woolwich \\
\hline 2130 & Control & Summer Hill \\
\hline 2204 & Control & Marrickville, Marrickville Metro, Marrickville South \\
\hline
\end{tabular}


Table A2: Effect of Lockout Laws - One-Bedroom Dwellings

\begin{tabular}{|c|c|c|c|c|}
\hline $\begin{array}{l}\text { Dependent variable: } \\
\text { MedianWeeklyRent }\end{array}$ & [1] OLS & $\begin{array}{l}\text { [2] Dif-in-Dif } \\
\text { No Controls }\end{array}$ & $\begin{array}{l}\text { [3] Dif-in-Dif } \\
\text { w/ Controls }\end{array}$ & $\begin{array}{l}\text { [4] Dif-in-Dif } \\
\text { Fixed Effects }\end{array}$ \\
\hline Sample periods used & Jun14-Dec15 & Jun13-Dec15 & Jun13-Dec15 & Jun13-Dec15 \\
\hline Flock & $\begin{array}{l}-26.76 \\
(22.95)\end{array}$ & $\begin{array}{c}17.49 \\
(26.63)\end{array}$ & $\begin{array}{l}-17.96 \\
(22.74)\end{array}$ & \\
\hline Flock*Post (DID Estimator) & & $\begin{array}{l}-7.51 \\
(5.89)\end{array}$ & $\begin{array}{l}-11.45^{*} \\
(6.41)\end{array}$ & $\begin{array}{l}-9.89 \\
(5.94)\end{array}$ \\
\hline $\mathrm{KmsCBD}$ & $\begin{array}{l}-12.00 \\
(7.68)\end{array}$ & & $\begin{array}{l}-11.84 \\
(7.42)\end{array}$ & \\
\hline$\%$ Renters & $\begin{array}{c}2.61 \\
(1.62)\end{array}$ & & $\begin{array}{c}2.73 \\
(1.68)\end{array}$ & \\
\hline$\%$ Singles & $\begin{array}{l}-3.52 \\
(5.41)\end{array}$ & & $\begin{array}{l}-3.11 \\
(5.12)\end{array}$ & \\
\hline AvgNumChild & $\begin{array}{l}136.35 \\
(88.39)\end{array}$ & & $\begin{array}{l}133.73 \\
(92.16)\end{array}$ & \\
\hline MedAge & $\begin{array}{l}-3.91 \\
(3.80)\end{array}$ & & $\begin{array}{l}-3.72 \\
(3.65)\end{array}$ & \\
\hline MedIncome & $\begin{array}{c}0.05 \\
(0.03)\end{array}$ & & $\begin{array}{c}0.05 \\
(0.03)\end{array}$ & \\
\hline SchoolsPer 1000 & $\begin{array}{c}-27.58 * * \\
(12.22)\end{array}$ & & $\begin{array}{c}-31.80 * * \\
(13.49)\end{array}$ & \\
\hline Sep13 & & $\begin{array}{l}-1.83 \\
(4.65)\end{array}$ & $\begin{array}{l}-0.95 \\
(4.80)\end{array}$ & $\begin{array}{l}-1.67 \\
(9.11)\end{array}$ \\
\hline Dec13 & & $\begin{array}{l}-0.78 \\
(5.82)\end{array}$ & $\begin{array}{c}0.98 \\
(5.04)\end{array}$ & $\begin{array}{c}0.88 \\
(4.54)\end{array}$ \\
\hline Jun14 & & $\begin{array}{c}13.49^{* *} \\
(5.65)\end{array}$ & $\begin{array}{c}17.51 * * * \\
(6.50)\end{array}$ & $\begin{array}{l}16.54 * * * \\
(5.66)\end{array}$ \\
\hline Sep14 & $\begin{array}{l}-5.98 \\
(4.40)\end{array}$ & $\begin{array}{c}5.80 \\
(6.65)\end{array}$ & $\begin{array}{l}11.55^{*} \\
(6.15)\end{array}$ & $\begin{array}{l}10.40^{*} \\
(5.17)\end{array}$ \\
\hline Dec14 & $\begin{array}{c}3.11 \\
(5.88)\end{array}$ & $\begin{array}{l}17.29 * * * \\
(5.84)\end{array}$ & $\begin{array}{l}20.67 * * * \\
(5.45)\end{array}$ & $\begin{array}{l}20.26 * * * \\
(4.59)\end{array}$ \\
\hline Mar15 & $\begin{array}{c}5.10 \\
(4.72)\end{array}$ & $\begin{array}{l}19.73 * * * \\
(3.76)\end{array}$ & $\begin{array}{l}22.51 * * * \\
(4.38)\end{array}$ & $\begin{array}{l}20.50 * * * \\
(3.80)\end{array}$ \\
\hline Jun15 & $\begin{array}{c}3.31 \\
(5.77)\end{array}$ & $\begin{array}{c}16.57 * * \\
(6.95)\end{array}$ & $\begin{array}{l}20.76 * * * \\
(7.18)\end{array}$ & $\begin{array}{l}20.27 * * * \\
(6.39)\end{array}$ \\
\hline Sep15 & $\begin{array}{l}-0.09 \\
(5.36)\end{array}$ & $\begin{array}{l}11.20 \\
(6.69)\end{array}$ & $\begin{array}{c}17.84 * * \\
(6.93)\end{array}$ & $\begin{array}{l}14.08 * * * \\
(5.80)\end{array}$ \\
\hline Dec15 & $\begin{array}{c}16.36^{* * *} \\
(5.79)\end{array}$ & $\begin{array}{l}27.17 * * * \\
(5.99)\end{array}$ & $\begin{array}{l}34.20 * * * \\
(7.01)\end{array}$ & $\begin{array}{l}30.13 * * * \\
(6.08)\end{array}$ \\
\hline Intercept & $\begin{array}{c}521.16 \\
(543.09)\end{array}$ & $\begin{array}{l}456.57 \\
(10.69)\end{array}$ & $\begin{array}{c}464.45 \\
(523.72)\end{array}$ & \\
\hline $\begin{array}{l}R^{2} \\
N\end{array}$ & $\begin{array}{c}0.309 \\
261\end{array}$ & $\begin{array}{c}0.304 \\
370\end{array}$ & $\begin{array}{c}0.326 \\
370\end{array}$ & $\begin{array}{c}0.163 \\
370\end{array}$ \\
\hline
\end{tabular}

Note: Standard errors robust to heteroscedasticity and postcode clusters are in parentheses. For the fixedeffects regression [4], the within $R^{2}$ coefficient is reported.

$* \mathrm{p}<0.1, * * \mathrm{p}<0.05, * * * \mathrm{p}<0.01$. 
Table A3: Effect of Lockout Laws - 2 Bedroom Dwellings

\begin{tabular}{|c|c|c|c|c|}
\hline $\begin{array}{l}\text { Dependent variable: } \\
\text { MedianWeeklyRent }\end{array}$ & [1] OLS & $\begin{array}{l}\text { [2] Dif-in-Dif } \\
\text { No Controls }\end{array}$ & $\begin{array}{l}\text { [3] Dif-in-Dif } \\
\text { w/ Controls }\end{array}$ & $\begin{array}{l}\text { [4] Dif-in-Dif } \\
\text { Fixed Effects }\end{array}$ \\
\hline Sample periods used & Jun14-Dec15 & Jun13-Dec15 & Jun13-Dec15 & Jun13-Dec15 \\
\hline Flock & $\begin{array}{c}-1.40 \\
(19.21)\end{array}$ & $\begin{array}{c}48.78 * * \\
(19.56)\end{array}$ & $\begin{array}{c}-5.38 \\
(19.98)\end{array}$ & \\
\hline Flock*Post (DID Estimator) & & $\begin{array}{c}2.14 \\
(8.74)\end{array}$ & $\begin{array}{c}1.74 \\
(8.75)\end{array}$ & $\begin{array}{c}2.67 \\
(8.51)\end{array}$ \\
\hline $\mathrm{KmsCBD}$ & $\begin{array}{c}-32.10 * * * \\
(6.33)\end{array}$ & & $\begin{array}{c}-30.59 * * * \\
(6.17)\end{array}$ & \\
\hline$\%$ Renters & $\begin{array}{c}1.09 \\
(1.71)\end{array}$ & & $\begin{array}{c}1.27 \\
(1.64)\end{array}$ & \\
\hline$\%$ Singles & $\begin{array}{c}2.79 \\
(4.81)\end{array}$ & & $\begin{array}{c}1.78 \\
(4.73)\end{array}$ & \\
\hline AvgNumChild & $\begin{array}{l}110.20 \\
(78.35)\end{array}$ & & $\begin{array}{c}93.51 \\
(74.49)\end{array}$ & \\
\hline MedAge & $\begin{array}{c}4.20 \\
(4.12)\end{array}$ & & $\begin{array}{c}3.29 \\
(3.90)\end{array}$ & \\
\hline MedIncome & $\begin{array}{c}0.04 \\
(0.03)\end{array}$ & & $\begin{array}{l}0.05^{*} \\
(0.03)\end{array}$ & \\
\hline SchoolsPer 1000 & $\begin{array}{l}-16.13 \\
(13.07)\end{array}$ & & $\begin{array}{l}-19.30 \\
(13.15)\end{array}$ & \\
\hline Sep13 & & $\begin{array}{l}-7.75 \\
(4.88)\end{array}$ & $\begin{array}{l}-7.67 \\
(4.92)\end{array}$ & $\begin{array}{l}-7.75 \\
(4.87)\end{array}$ \\
\hline Dec13 & & $\begin{array}{c}6.02 \\
(4.89)\end{array}$ & $\begin{array}{c}6.26 \\
(5.07)\end{array}$ & $\begin{array}{c}5.25 \\
(4.81)\end{array}$ \\
\hline Jun14 & & $\begin{array}{l}26.93 * * * \\
(5.65)\end{array}$ & $\begin{array}{l}27.37 * * * \\
(5.78)\end{array}$ & $\begin{array}{l}26.85 * * * \\
(5.59)\end{array}$ \\
\hline Sep14 & $\begin{array}{l}-4.38 \\
(4.79)\end{array}$ & $\begin{array}{l}22.62 * * * \\
(6.38)\end{array}$ & $\begin{array}{l}22.98 * * * \\
(6.42)\end{array}$ & $\begin{array}{l}22.54 * * * \\
(6.31)\end{array}$ \\
\hline Dec14 & $\begin{array}{l}-1.21 \\
(5.05)\end{array}$ & $\begin{array}{l}25.65 * * * \\
(6.23)\end{array}$ & $\begin{array}{l}26.17 * * * \\
(6.32)\end{array}$ & $\begin{array}{l}25.57 * * * \\
(6.17)\end{array}$ \\
\hline Mar15 & $\begin{array}{c}6.65 \\
(4.45)\end{array}$ & $\begin{array}{c}33.86^{* * *} \\
(7.85)\end{array}$ & $\begin{array}{l}33.82 * * * \\
(7.47)\end{array}$ & $\begin{array}{l}31.29 * * * \\
(6.74)\end{array}$ \\
\hline Jun15 & $\begin{array}{c}11.87 * * \\
(5.25)\end{array}$ & $\begin{array}{l}38.93 * * * \\
(6.84)\end{array}$ & $\begin{array}{l}39.22 * * * \\
(6.88)\end{array}$ & $\begin{array}{c}38.85 * * * \\
(6.80)\end{array}$ \\
\hline Sep15 & $\begin{array}{c}6.64 \\
(4.78)\end{array}$ & $\begin{array}{l}32.80 * * * \\
(5.28)\end{array}$ & $\begin{array}{l}34.17 * * * \\
(5.51)\end{array}$ & $\begin{array}{l}32.72 * * * \\
(5.26)\end{array}$ \\
\hline Dec15 & $\begin{array}{l}35.06 * * * \\
(3.77)\end{array}$ & $\begin{array}{l}61.74 * * * \\
(7.69)\end{array}$ & $\begin{array}{l}62.34 * * * \\
(7.35)\end{array}$ & $\begin{array}{l}59.18 * * * \\
(6.54)\end{array}$ \\
\hline Intercept & $\begin{array}{c}142.71 \\
(528.62)\end{array}$ & $\begin{array}{l}598.18 \\
(13.25)\end{array}$ & $\begin{array}{c}228.42 \\
(515.37)\end{array}$ & \\
\hline $\begin{array}{l}R^{2} \\
N\end{array}$ & $\begin{array}{c}0.598 \\
278\end{array}$ & $\begin{array}{c}0.124 \\
399\end{array}$ & $\begin{array}{c}0.610 \\
399\end{array}$ & $\begin{array}{c}0.436 \\
398\end{array}$ \\
\hline
\end{tabular}

Note: Standard errors robust to heteroscedasticity and postcode clusters are in parentheses. For the fixedeffects regression [4], the within $R^{2}$ coefficient is reported.

$* \mathrm{p}<0.1, * * \mathrm{p}<0.05, * * * \mathrm{p}<0.01$. 
Table A4: Effect of Lockout Laws - 3 Bedroom Dwellings

\begin{tabular}{|c|c|c|c|c|}
\hline $\begin{array}{l}\text { Dependent variable: } \\
\text { MedianWeeklyRent }\end{array}$ & [1] OLS & $\begin{array}{l}\text { [2] Dif-in-Dif } \\
\text { No Controls }\end{array}$ & $\begin{array}{l}\text { [3] Dif-in-Dif } \\
\text { w/ Controls }\end{array}$ & $\begin{array}{l}\text { [4] Dif-in-Dif } \\
\text { Fixed Effects }\end{array}$ \\
\hline Sample periods used & Jun14-Dec15 & Jun13-Dec15 & Jun13-Dec15 & Jun13-Dec15 \\
\hline Flock & $\begin{array}{l}-57.50 \\
(39.75)\end{array}$ & $\begin{array}{l}-15.60 \\
(39.89)\end{array}$ & $\begin{array}{l}-78.89 * \\
(40.73)\end{array}$ & \\
\hline Flock*Post (DID Estimator) & & $\begin{array}{c}25.57^{* * *} \\
(10.21)\end{array}$ & $\begin{array}{c}19.45^{* *} \\
(9.58)\end{array}$ & $\begin{array}{c}19.41 * * \\
(9.04)\end{array}$ \\
\hline $\mathrm{KmsCBD}$ & $\begin{array}{c}-33.31 * * \\
(12.71)\end{array}$ & & $\begin{array}{c}-35.03 * * * \\
(11.69)\end{array}$ & \\
\hline$\%$ Renters & $\begin{array}{l}9.27 * * * \\
(2.50)\end{array}$ & & $\begin{array}{l}9.32 * * * \\
(2.42)\end{array}$ & \\
\hline$\%$ Singles & $\begin{array}{c}16.57 * * \\
(8.05)\end{array}$ & & $\begin{array}{l}16.13 * * \\
(7.54)\end{array}$ & \\
\hline AvgNumChild & $\begin{array}{c}641.88 * * * \\
(127.87)\end{array}$ & & $\begin{array}{c}654.40 * * * \\
(123.44)\end{array}$ & \\
\hline MedAge & $\begin{array}{l}19.01 * * * \\
(5.58)\end{array}$ & & $\begin{array}{l}18.38 * * * \\
(5.07)\end{array}$ & \\
\hline MedIncome & $\begin{array}{c}0.15^{* * * *} \\
(0.03)\end{array}$ & & $\begin{array}{c}0.16^{* * * *} \\
(0.03)\end{array}$ & \\
\hline SchoolsPer 1000 & $\begin{array}{l}-51.72 * * * \\
(13.45)\end{array}$ & & $\begin{array}{c}-53.50 * * * \\
(13.86)\end{array}$ & \\
\hline Sep13 & & $\begin{array}{l}-16.89 \\
(10.22)\end{array}$ & $\begin{array}{l}-19.64 * \\
(10.45)\end{array}$ & $\begin{array}{c}-19.82 * * \\
(9.25)\end{array}$ \\
\hline Dec13 & & $\begin{array}{c}1.26 \\
(17.14)\end{array}$ & $\begin{array}{c}5.59 \\
(16.44)\end{array}$ & $\begin{array}{l}10.65 \\
(16.26)\end{array}$ \\
\hline Jun14 & & $\begin{array}{c}14.37 \\
(11.67)\end{array}$ & $\begin{array}{r}23.08 * * \\
(11.42)\end{array}$ & $\begin{array}{r}23.63 * * \\
(10.71)\end{array}$ \\
\hline Sep14 & $\begin{array}{l}-14.82 \\
(15.30)\end{array}$ & $\begin{array}{c}9.45 \\
(13.45)\end{array}$ & $\begin{array}{c}8.26 \\
(14.27)\end{array}$ & $\begin{array}{c}7.27 \\
(13.58)\end{array}$ \\
\hline Dec14 & $\begin{array}{l}-12.81 \\
(13.13)\end{array}$ & $\begin{array}{c}4.93 \\
(11.59)\end{array}$ & $\begin{array}{l}10.35 \\
(10.90)\end{array}$ & $\begin{array}{l}17.08 \\
(10.83)\end{array}$ \\
\hline Mar15 & $\begin{array}{c}19.43 \\
(14.23)\end{array}$ & $\begin{array}{r}41.57 * * \\
(14.63)\end{array}$ & $\begin{array}{c}42.55 * * * \\
(14.71)\end{array}$ & $\begin{array}{c}44.21 * * * \\
(14.59)\end{array}$ \\
\hline Jun15 & $\begin{array}{l}35.13^{* *} \\
(15.99)\end{array}$ & $\begin{array}{l}52.15 * * * \\
(13.64)\end{array}$ & $\begin{array}{c}58.39 * * * \\
(13.62)\end{array}$ & $\begin{array}{c}62.11 * * * \\
(13.35)\end{array}$ \\
\hline Sep15 & $\begin{array}{c}17.91 \\
(14.90)\end{array}$ & $\begin{array}{c}37.76^{* * * *} \\
(13.09)\end{array}$ & $\begin{array}{c}41.18 * * * \\
(13.60)\end{array}$ & $\begin{array}{c}40.33 * * * \\
(12.89)\end{array}$ \\
\hline Dec15 & $\begin{array}{l}51.31 * * * \\
(12.88)\end{array}$ & $\begin{array}{c}72.24 * * * \\
(11.80)\end{array}$ & $\begin{array}{c}74.19 * * * \\
(11.14)\end{array}$ & $\begin{array}{c}75.04 * * * \\
(10.87)\end{array}$ \\
\hline Intercept & $\begin{array}{c}-2597.77 * * * \\
(635.09)\end{array}$ & $\begin{array}{l}869.28 \\
(25.59)\end{array}$ & $\begin{array}{c}-2586.72 * * * * \\
(580.64)\end{array}$ & \\
\hline $\begin{array}{l}R^{2} \\
N\end{array}$ & $\begin{array}{c}0.623 \\
257\end{array}$ & $\begin{array}{c}0.038 \\
371\end{array}$ & $\begin{array}{c}0.648 \\
371\end{array}$ & $\begin{array}{c}0.210 \\
371\end{array}$ \\
\hline
\end{tabular}

Note: Standard errors robust to heteroscedasticity and postcode clusters are in parentheses. For the fixedeffects regression [4], the within $R^{2}$ coefficient is reported.

$* \mathrm{p}<0.1, * * \mathrm{p}<0.05, * * * \mathrm{p}<0.01$ 
Table A5: Effect of Lockout Laws -3 and 4+ Bedroom Dwellings

\begin{tabular}{|c|c|c|c|c|}
\hline $\begin{array}{l}\text { Dependent variable: } \\
\text { MedianWeeklyRent }\end{array}$ & [1] OLS & $\begin{array}{l}\text { [2] Dif-in-Dif } \\
\text { No Controls }\end{array}$ & $\begin{array}{l}\text { [3] Dif-in-Dif } \\
\text { w/ Controls }\end{array}$ & $\begin{array}{l}\text { [4] Dif-in-Dif } \\
\text { Fixed Effects }\end{array}$ \\
\hline Sample periods used & Jun14-Dec15 & Jun13-Dec15 & Jun13-Dec15 & Jun13-Dec15 \\
\hline \multicolumn{5}{|c|}{ Bedroom type (reference: 3 bedroom) } \\
\hline 4+ Bedroom & $\begin{array}{l}355.38 * * * \\
(64.65)\end{array}$ & $\begin{array}{l}377.71 * * * \\
(98.38)\end{array}$ & $\begin{array}{l}363.90 * * * \\
(68.48)\end{array}$ & $\begin{array}{l}388.01 * * * \\
(69.14)\end{array}$ \\
\hline Flock & $\begin{array}{l}-83.65 \\
(60.08)\end{array}$ & $\begin{array}{c}-119.07 * \\
(65.76)\end{array}$ & $\begin{array}{c}-127.81 * * \\
(61.44)\end{array}$ & \\
\hline Flock*Post (DID Estimator) & & $\begin{array}{l}78.68 * * * \\
(26.88)\end{array}$ & $\begin{array}{c}62.28 * * \\
(24.90)\end{array}$ & $\begin{array}{c}55.86 * * \\
(26.86)\end{array}$ \\
\hline $\mathrm{KmsCBD}$ & $\begin{array}{l}-7.86 \\
(22.25)\end{array}$ & & $\begin{array}{l}-14.42 \\
(19.53)\end{array}$ & \\
\hline$\%$ Renters & $\begin{array}{c}11.01 * * * \\
(3.93)\end{array}$ & & $\begin{array}{c}10.74 * * * \\
(3.40)\end{array}$ & \\
\hline$\%$ Singles & $\begin{array}{l}41.01 * * * \\
(14.63)\end{array}$ & & $\begin{array}{c}35.47 * * * \\
(12.69)\end{array}$ & \\
\hline AvgNumChild & $\begin{array}{c}864.17 * * * \\
(176.79)\end{array}$ & & $\begin{array}{c}817.82 * * * \\
(160.00)\end{array}$ & \\
\hline MedAge & $\begin{array}{l}11.57 \\
(7.67)\end{array}$ & & $\begin{array}{l}12.84^{*} \\
(6.70)\end{array}$ & \\
\hline MedIncome & $\begin{array}{c}0.37 * * * \\
(0.09)\end{array}$ & & $\begin{array}{c}0.33 * * * \\
(0.08)\end{array}$ & \\
\hline SchoolsPer 1000 & $\begin{array}{l}-81.18 * * * \\
(22.63)\end{array}$ & & $\begin{array}{l}-76.08 * * * \\
(20.48)\end{array}$ & \\
\hline Sep13 & & $\begin{array}{l}-11.14 \\
(30.11)\end{array}$ & $\begin{array}{l}-9.83 \\
(26.58)\end{array}$ & $\begin{array}{l}-7.09 \\
(26.37)\end{array}$ \\
\hline Dec13 & & $\begin{array}{c}11.72 \\
(19.05)\end{array}$ & $\begin{array}{c}15.34 \\
(16.33)\end{array}$ & $\begin{array}{l}29.25^{*} \\
(16.37)\end{array}$ \\
\hline Jun14 & & $\begin{array}{c}26.10 \\
(16.32)\end{array}$ & $\begin{array}{c}37.08 * * * \\
(13.00)\end{array}$ & $\begin{array}{c}43.03 * * * \\
(12.09)\end{array}$ \\
\hline Sep14 & $\begin{array}{c}9.21 \\
(20.75)\end{array}$ & $\begin{array}{l}-3.09 \\
(20.88)\end{array}$ & $\begin{array}{l}15.37 \\
(16.66)\end{array}$ & $\begin{array}{c}14.58 \\
(16.60)\end{array}$ \\
\hline Dec14 & $\begin{array}{l}29.05 \\
(24.94)\end{array}$ & $\begin{array}{c}16.12 \\
(21.43)\end{array}$ & $\begin{array}{l}34.31^{*} \\
(19.19)\end{array}$ & $\begin{array}{l}42.10 * * \\
(18.89)\end{array}$ \\
\hline Mar15 & $\begin{array}{l}45.38^{*} \\
(26.38)\end{array}$ & $\begin{array}{c}33.41 \\
(25.71)\end{array}$ & $\begin{array}{l}48.66 * * \\
(20.95)\end{array}$ & $\begin{array}{l}51.72 * * \\
(20.89)\end{array}$ \\
\hline Jun15 & $\begin{array}{l}65.94 * * * \\
(20.24)\end{array}$ & $\begin{array}{c}63.00 * * * \\
(18.83)\end{array}$ & $\begin{array}{c}72.06 * * * \\
(16.30)\end{array}$ & $\begin{array}{l}79.93 * * * \\
(15.69)\end{array}$ \\
\hline Sep15 & $\begin{array}{l}41.34 \\
(26.62)\end{array}$ & $\begin{array}{c}27.07 \\
(28.11)\end{array}$ & $\begin{array}{l}45.50^{*} \\
(24.16)\end{array}$ & $\begin{array}{l}50.82 * * \\
(23.57)\end{array}$ \\
\hline Dec15 & $\begin{array}{c}88.17 * * * \\
(28.23)\end{array}$ & $\begin{array}{c}69.32 * * * \\
(24.43)\end{array}$ & $\begin{array}{c}90.45 * * * \\
(23.75)\end{array}$ & $\begin{array}{c}93.20 * * * \\
(21.87)\end{array}$ \\
\hline Intercept & $\begin{array}{c}-5201.27 * * * \\
(1423.39) \\
\end{array}$ & $\begin{array}{l}878.27 \\
(31.44)\end{array}$ & $\begin{array}{c}-4624.70 * * * \\
(1206.85) \\
\end{array}$ & \\
\hline$R^{2}$ & 0.650 & 0.363 & 0.662 & 0.581 \\
\hline$N$ & 355 & 469 & 469 & 469 \\
\hline
\end{tabular}

Note: Standard errors robust to heteroscedasticity and postcode clusters are in parentheses. For the fixedeffects regression [4], the within $R^{2}$ coefficient is reported.

$* \mathrm{p}<0.1, * * \mathrm{p}<0.05, * * * \mathrm{p}<0.01$. 